\title{
IMPACTO DE LA EDUCACIÓN \\ EN EL EMPRENDIMIENTO. MAKING-OF Y ANÁLISIS \\ DE TRES GRUPOS DE DISCUSIÓN'
}

\section{THE IMPACT OF EDUCATION \\ ON ENTREPRENEURSHIP. MAKING OF AND ANALYSIS \\ OF THREE DISCUSSION GROUPS}

\author{
O IMPACTO DA EDUCAÇÃO \\ NO EMPREENDEDORISMO. MAKING-OF E ANÁLISE \\ DE TRES GRUPOS DE DISCUSSÃO.
}

\section{Ma Isabel Luis Rico, Carmen Palmero Cámara y Ma Camino Escolar Llamazares}

UNIVERSIDAD DE BURGOS, ESPAÑA

\begin{abstract}
RESUMEN: Partiendo del carácter estratégico que la formación tiene para el empleo, se considera que uno de los campos donde puede ser más determinante es en el emprendimiento. Es por lo tanto, necesario focalizar la atención en el impacto que la educación secundaria, profesional y superior tiene en las tasas de emprendimiento. Igualmente, es conveniente valorar y proponer criterios eficaces para la toma de decisiones de la política educativa ordenada a implementar las competencias adecuadas y el espíritu emprendedor entre los jóvenes. En este sentido, el objetivo de este trabajo es analizar las necesidades educativas en relación con el emprendimiento, a través de Grupos de Discusión formados por representantes de colectivos implicados en la creación de empresas. Presentamos el making-of de los Grupos de Discusión y el análisis de las aportaciones a dichos grupos, a través de la utilización de metodologías cualitativas. Los resultados del estudio muestran una discrepancia en cuanto a las necesidades educativas y expectativas entre emprendedores y los servicios especializados en emprendimiento y educadores. Se concluye la utilidad de estos resultados como un primer paso para redefinir el curriculum de la educación secundaria obligatoria y la enseñanza profesional.
\end{abstract}

PALABRAS CLAVE: Emprendimiento; Joven; Educación; Grupo de Discusión; Competencia.

ABSTRACT: Building on the strategic character that education has on employment, one of the fields where it has a more determinant impact is on entrepreneurship. Therefore, it is necessary to focus on the impact of secondary, vocational and higher education on the entrepreneurship rates. Similarly, it is advisable to evaluate and propose effective criteria to take decision in educational policy in order to implement the ade- 
quate competences and the entrepreneurial spirit among young people. The goal of this study is to analyse the educational needs related to entrepreneurship, through discussion groups made of representatives of the groups involved in the creation of firms. We show the making-of of the discussion groups and the analysis of the contributions of these groups, at the methodological level qualitative techniques. The results show a discrepance regarding the educational needs and expectations between entrepreneurs and the agencies specialize in entrepreneurship and educators. We conclude that our results are useful as a first step to redefine the curriculum of compulsory secondary education and vocational training.

KEYWORDS: Entrepreneurship; Young People; Education; Discussion Group; Competence.

RESUMO: A partir da natureza estratégica que a formação tem para o emprego, considera-se que um dos campos onde pode ser mais determinante é no empreendedorismo. Assim, é fundamental focalizar a atenção no impacto que a educação secundária, profissional e superior têm nas taxas empreendedoras. Igualmente, é importante valorizar e propor critérios eficazes para a tomada de decisões na política educativa organizada a implementar as competências adequadas e o espírito empreendedor entre os jovens. Neste sentido, o objetivo deste trabalho é analisar as necessidades educativas na relação com o empreendedorismo, através de Grupos de Discussão formados por representantes de colectivos implicados na criação de empresas. Apresentamos o Making-of dos Grupos de Discussão e a análise das contribuições a esses grupos, através da utilização de metodologias qualitativas. Os resultados do estudo mostram uma discrepância quanto às necessidades educativas e expetativas entre os empreendedores e os serviços especializados em empreendedorismo e educadores. Conclui-se a utilidade destes resultados como um primeiro passo para redefinir o curriculum da educação secundária obrigatória e o ensino profissional.

PALAVRAS-CHAVE: Empreendedorismo; Jovem; Educação; Grupo de Discussão; Competência. 


\section{Introducción. Educación y emprendimiento}

Uno de los debates socioeducativos de las últimas décadas está centrado en el carácter estratégico de la formación para el empleo (Jiménez, Palmero \& Alonso, 2005; Jiménez Palmero, Palmero Cámara \& Jiménez Eguizábal, 2012), intentado optimizar los tiempos educativos y sociales en el proceso de socialización de los jóvenes. A lo largo de los últimos treinta años, ha aumentado la preocupación de economistas, sociólogos y pedagogos por explicar las complejas interacciones entre educación y empleo (Bas Peña, 2007; Martínez-Mediano, Lord y Rioperez Losada, 2013), lo que ha impulsado un renovado interés por la educación como variable explicativa, y en ocasiones determinante, de la política laboral y de la problemática empresarial (Jiménez Palmero et al., 2012).

Precisamente, uno de los campos donde el papel de la educación puede resultar más determinante es el del emprendimiento, fenómeno de singular relevancia en los últimos años debido a la necesidad de superar los constantes y crecientes problemas económicos por los que la mayoría de las sociedades están atravesando y que cada año afecta a nivel mundial a casi 500 millones de personas relacionadas con la creación de una nueva empresa (Jiménez Palmero et al., 2012; Moya, 2008, Pérez González, 2013).

Entendemos el emprendimiento como la creación de ideas, empresas y patentes así como todo el proceso de su gestación, incluso en aquellos casos en los que no se alcanza su puesta en práctica, habiendo sido señalado por diversos autores como uno de los componentes clave para el crecimiento y desarrollo social y económico (Agarwal, Audretsch \& Sarkar, 2007; Baumol, 2004; Baumol \& Strom, 2007; Jiménez Palmero et al., 2012; Zacharakis, Bygrave \& Shepherd, 2000). El emprendimiento se encuentra íntimamente ligado a la innovación, al crecimiento de la productividad, la competitividad, el crecimiento económico, la creación de empleo e incluso el éxito a nivel personal (Grilo \& Thurik, 2005; Luis, De la Torre, Gañan, Palmero \& Jiménez, 2013). En este sentido, los emprendedores innovan, transforman sus ideas en negocios, crean empresas, desarrollan proyectos para ofrecer productos y servicios diferentes, contribuyendo así a la generación de empleo y

\section{Introduction. Education and entrepreneurship}

One of the recent decades socio-educational debates focuses on the strategic nature of the employment training (Jiménez, Palmero \& Alonso, 2005; Jiménez Palmero, Palmero Cámara and Jiménez Eguizábal, 2012), trying to optimize the educational and social times for young people's socialization process. Over the past thirty years, the concern of economists, sociologists and educators is focused on explaining the complex interactions between education and employment (Bas Peña, 2007; Martínez - Mediano, Lord \& Rioperez Losada, 2013), what has boosted a renewed interest on education as an explanatory variable, and sometimes decisive, in labour policy and business problems (Jiménez Palmero et al., 2012).

One of the fields where the role of education can be more decisive is precisely that of entrepreneurship, a phenomenon of singular importance in recent years due to the need of overcoming the constant and growing economic problems that most societies are facing and that every year affects worldwide to almost $500 \mathrm{mi}$ llion people related to the starting a new business (Jiménez Palmero et al., 2012; Moya, 2008, Pérez González, 2013).

We understand entrepreneurship as the creation of ideas, companies and patents as well as their incubation process, even in those cases in which their implementation is not fulfilled, that have been pointed out by several authors as one of the key components for growth and economic and social development (Agarwal, Audretsch \& Sarkar, 2007; Baumol, 2004; Baumol \& Strom, 2007; Jiménez Palmero et al., 2012; Zacharakis, Bygrave \& Shepherd, 2000). Entrepreneurship is closely related to innovation, productivity growth, competitiveness, economic growth, the creation of employment and even the success at a personal level (Grilo \& Thurik, 2005; Luis De la Torre, Gañan, Palmero \& Jiménez, 2013). In this regard, entrepreneurs innovate, transform their ideas into businesses, create companies, develop projects to offer different products and services, thus contributing to the generation of employment and economic and social wealth in the territory where they settle (García Cabrera et al., 
riqueza económica y social en el territorio donde se asientan (Garcia Cabrera et al., 2014; Pérez González, 2013; Valliere \& Peterson, 2009).

El emprendimiento como fenómeno multidimensional se ha estudiado a nivel individual, empresarial, regional, sectorial y nacional (Wennekers \& Thurik, 1999; Davidsson, 2004; Jiménez Palmero et al., 2012). Sin embargo, este tipo de estudios han considerado casi de forma exclusiva variables de carácter económico, lo que ha impedido explicar gran parte de la variación en la actividad emprendedora (Freytag \& Thurik, 2007; Uhlaner \& Thurik, 2007). En consecuencia, tal y como recogen Jiménez $\mathrm{Pal}$ mero et al. (2012) es necesario focalizar la atención en el impacto que la educación secundaria, profesional y superior tiene en las tasas de emprendimiento, entendiendo por impacto la medida en la que la educación fomenta las tasas de creación de nuevas empresas, siendo avalada esta relación positiva por estudios como el de McClelland (1975), Delmar y Davidsson (2000), Van Gelderen y Jansen (2006) y Jiménez Palmero et al. (2012).

En esta línea, nuestro trabajo profundiza en la compleja interacción entre educación y emprendimiento centrando la atención en la dimensión formativa, pues concebimos el fenómeno del emprendimiento como una de las necesidades actuales de la juventud para lograr su independencia (Pérez González, 2013), que deben ser abordadas desde el plano de la educación. Tal y como señala Perrenooud (2009), consideramos fundamental implementar en los planes de estudio, desde la enseñanza obligatoria pasando por la enseñanza profesional hasta llegar a la universitaria, el emprendimiento como competencia a trabajar. Competencia, por otra parte, esencial para facilitar la transición entre la formación reglada y el mundo laboral (Martinez-Mediano et al., 2013), si consideramos como tal término el conjunto de conocimientos, los procedimientos y las actitudes que permitirán a los alumnos adaptarse a una sociedad inmersa en un entorno económico y social dinámico y cambiante, abordar los problemas desde una perspectiva multidisciplinaria y no fragmentada y contar con una formación integral basada en el desarrollo de la inteligencia cognitiva pero también de la inteligencia emocional (Attewell, 2009; Escudero Muñoz, 2009; Gonazi, 2003; Cano García, 2008; García Cabrera et al., 2014).
2014;) Pérez González, 2013; Valliere \& Peterson, 2009).

Entrepreneurship as a multidimensional phenomenon has been studied at individual, corporate, regional, sectoral and national level (Wennekers \& Thurik, 1999; Davidsson, 2004; Jiménez Palmero et al., 2012). However, such studies have considered almost exclusively economic variables, thus has prevent to explain much of the variation in entrepreneurial activity (Freytag \& Thurik, 2007; Uhlaner \& Thurik, 2007). As a result, as collected by Jiménez Palmero et al. (2012) it is necessary to focus our attention on the impact that secondary education, vocational and higher education have over the entrepreneurship rates, taking as an impact the way in which education boost new business creation rates, being this positive relationship supported by studies such that the one of McClelland (1975), Delmar and Davidsson (2000), Van Gelderen and Jansen (2006) and Jiménez Palmero et al. (2012).

In this line, our work delves into the complex interplay between education and entrepreneurship, focusing on the formative dimension, given that perceive the entrepreneurship phenomenon as one of the current needs of youth to achieve their independence (Pérez González, 2013), it should be addressed from the educational level. As Perrenooud (2009) points out, it is essential to implement it in education programs, from compulsory education through vocational education up to the University, entrepreneurship as a competence for working. It is essential to facilitate the transition between the education and the world of work (Martínez-Mediano et al., 2013), if we consider it as a jointly of knowledge, procedures and attitudes that will enable students to adapt to a society immersed in a dynamic and changing economic and social environment, to address the issues from a multidisciplinary non-fragmented perspective and integral training based on the development of cognitive but also emotional intelligence (Attewell, 2009; Escudero Muñoz, 2009; Gonazi, 2003; Cano García, 2008; García Cabrera et al., 2014).

As a result, education assumes in an intentional sphere, through its incorporation into the educative program, a claim to facilitate the incorporation of explicit knowledge that can provide useful competences and abilities or skills related to the creation 
En consecuencia, la educación asume de forma intencional, a través de su incorporación en el currículum académico, la pretensión de facilitar la incorporación de conocimientos explícitos que pueden proporcionar competencias y destrezas o habilidades útiles relacionadas con la creación de empresas a los alumnos. Siendo por lo tanto el curriculum el instrumento idóneo para la adquisición de competencias relacionadas con la creación de empresas. (Ahmad, Halim \& Zainal, 2010; Ahmad, Wilson \& Kummereow, 2011; Chandler \& Jansen, 1992; Fourie, 2008; García Cabrera et al., 2014; Man et al., 2002; Man, Lau \& Snape, 2008; Rathna \& Vijaya, 2009)

Así nuestra investigación se centra en conocer las competencias emprendedoras valoradas como necesarias para la creación de empresas por distintos grupos de interés de sectores relacionados con el emprendimiento, determinando la formación necesaria y los niveles adecuados en los que se han de incorporar en el currículum educativo. Siendo igualmente necesario establecer las dificultades actuales que existen para la creación de empresas.

Para ello, hemos optado, de entre las posibles vías metodológicas de estudio, el análisis de los Grupos de Discusión (GD) ya que permiten analizar desde un punto de vista cualitativo una realidad compleja proveniente de la interacción entre educación y emprendimiento. Igualmente, los GD son una vía complementaria a los estudios más cuantitativos (Jiménez Palmero et al., 2012) para poner en valor el fundamental papel que la educación tiene en las tasas de emprendimiento.

\section{Objetivos}

El objetivo general de la investigación de la que parte este trabajo se centra en determinar el impacto que la educación tiene en las tasas de emprendimiento, como uno de los factores que definen las interacciones sociales, económicas, políticas y éticas de un país, motivando cambios en los procesos de socialización e innovaciones curriculares que deben operarse en la formación de los jóvenes emprendedores en una sociedad de redes.

Para dar satisfacción al objetivo general descrito, la investigación se articula en tres fases en las que se enmarcan los objetivos específicos: of enterprises. Being therefore the educative program the ideal tool for the acquisition of skills related to the business creation. (Ahmad, Halim \& Zainal, 2010; Ahmad, Wilson \& Kummereow, 2011; Chandler \& Jansen, 1992; Fourie, 2008; García Cabrera et al., 2014; Man et al., 2002; Man, Lau \& Snape, 2008; Rathna \& Vijaya, 2009)

Our research thus focuses on acquiring entrepreneurial skills valued as necessary for the creation of enterprises by different stakeholders of sectors related to entrepreneurship, determining the necessary training and appropriate levels that have been incorporated into the educative program. Even though, it is equally necessary to establish the current difficulties that exist for the creation of enterprises.

In order to do that, we have chosen, from among the possible methodological ways of study, the analysis of Discussion Groups (DG) that enable to analyse from a complex reality coming from the interaction between education and entrepreneurship from a qualitative point of view. Also, the DG are a complement to the more quantitative studies via (Jiménez Palmero et al., 2012) to highlight the fundamental role that education has in entrepreneurship rates.

\section{Objectives}

The overall objective of the research from which this work comes, focuses on determining the impact of education on entrepreneurship rates, as one of the defining factors for social, economic, political and ethical interactions of a country, encouraging changes in the processes of socialization and curricular innovations that must be done in the training of young entrepreneurs in a society of networks.

To accomplish the general aim described, this research is structured in three phases in which we can find three specific objectives: 
- Fase exploratoria: El objetivo específico de esta fase es determinar la formación y competencias necesarias para crear empresa así como la motivación y las dificultades que existen para ello, a través de la información aportada por grupos de interés de sectores relacionados con el emprendimiento: emprendedores, expertos y técnicos en emprendimiento de entidades públicas y privadas y educadores, así como por la revisión teórica aportada por investigaciones centradas en las competencias para el emprendimiento.

- Fase de desarrollo: En función de los resultados alcanzados en la fase exploratoria se propondrá la elaboración de un instrumento de recogida de información con el objetivo de determinar la influencia que tienen las competencias emprendedoras en la educación de los jóvenes españoles de 16 a 18 años y poder así relacionar el impacto de la educación, a través de las competencias emprendedoras, en la tasas de emprendimiento.

- Fase de propuestas: El objetivo de esta fase es proponer acciones de mejora en política educativa curricular para satisfacer los objetivos generales de la investigación, en virtud de las conclusiones alcanzadas en las anteriores fases.

En el presente trabajo se muestran los resultados descriptivos de los grupos de discusión desarrollados dentro de la fase exploratoria de la investigación.

\section{Metodología de los grupos de discusión de la fase exploratoria}

\subsection{Participantes}

Participaron un total de veinticuatro agentes repartidos en tres Grupos de Discusión. El perfil de sujetos seleccionados para la realización de los GD se muestra en la tabla 1.

\subsection{Diseño}

El diseño propuesto integra técnicas de recogida de datos cualitativas destinadas a construir una base empírica desde la que dar respuesta al objetivo planteado. En concreto, se emplea la técnica de Entre-
- Exploratory phase: The specific objective of this phase is to determine needed training and skills to create a company as well as the motivation and existing difficulties for this purpose, through the information provided by stakeholders of sectors related to entrepreneurship: entrepreneurs, experts and technical specialized on entrepreneurship of public and private institutions and educators, as well as the theoretical review provided by researches focused on competencies for the entrepreneurship.

- Development phase: Depending on the results achieved in the exploratory phase there will be proposed the development of a tool for collecting information in order to determine the influence that entrepreneurial skills have on the education of young Spaniards aged 16 to 18 and thus to link the impact of education, through the entrepreneurial skills, in the entrepreneurship rates.

- Proposals phase: The aim of this phase is to propose improvement actions in educative program's policy in order to satisfy the general aims of the research, according to the results obtained in the previous phases.

This research show descriptive results from the discussion groups developed during the exploratory phase of the research.

\section{Methodology of the exploratory phase in discussion groups}

\subsection{Participants}

Twenty four agents for all over the Discussion Groups participate. The profile of the subjects selected for the realization of the DG is shown in table 1 .

\subsection{Design}

The proposed design integrates qualitative data collection techniques to build an empirical basis from which approach the stated objective. In particular, Group Interviews or Discussion Groups are emplo-

[ 226 ] Ma ISABEL LUIS RICO, CARMEN PALMERO CÁMARA Y Ma CAMINO ESCOLAR LLAMAZARES SIPS - PEDAGOGIA SOCIAL. REVISTA INTERUNIVERSITARIA [1139-1723 (2015) 25, 221-250] TERCERA ÉPOCA 
Tabla 1. Perfil de participantes en los grupos de discusión

\begin{tabular}{|c|c|c|c|}
\hline $\begin{array}{l}\text { GRUPO } \\
\text { DE INTERÉS }\end{array}$ & No & SEXO & PERFIL \\
\hline EMPRESARIOS & 12 & $\begin{array}{l}10 \text { hombres } \\
2 \text { mujeres }\end{array}$ & $\begin{array}{l}\text { Emprendedores de Burgos y provincia de las áreas de: consultoría infor- } \\
\text { mática, enseñanza de idiomas, nuevas tecnologías, construcción, consulto- } \\
\text { ría energética, grafología, fotografía, eficiencia energética, ingeniería, enolo- } \\
\text { gía y terapia ocupacional. }\end{array}$ \\
\hline $\begin{array}{l}\text { EXPERTOS } \\
\text { Y TÉCNICOS }\end{array}$ & 10 & $\begin{array}{l}5 \text { mujeres } \\
5 \text { hombres }\end{array}$ & $\begin{array}{l}\text { Representantes de: Cámara de Comercio, FAE (Confederación de Asocia- } \\
\text { ciones Empresariales de Burgos), FEC (Federación de Comercio de Bur- } \\
\text { gos), Área de Juventud del Ayuntamiento de Burgos, Unidad de Empleo } \\
\text { de la Universidad de Burgos, AJE (Asociación de Jóvenes Empresarios), } \\
\text { CEEI (Centro Europeo de Empresas e Innovación de Burgos), Dirección } \\
\text { Territorial de la ADE (Agencia Desarrollo Económico) de la Junta de Casti- } \\
\text { lla y León y SODEBUR (Sociedad para el Desarrollo de la Provincia de } \\
\text { Burgos) de la Diputación de Burgos }\end{array}$ \\
\hline EDUCADORES & 3 & $\begin{array}{c}2 \text { hombres } \\
1 \text { mujer }\end{array}$ & Orientadores del IES de Burgos, Lerma y Miranda de Ebro \\
\hline
\end{tabular}

Table 1. Participants' profile for discussion groups

\begin{tabular}{|c|c|c|c|}
\hline $\begin{array}{l}\text { INTEREST } \\
\text { GROUP }\end{array}$ & No & SEX & PROFILE \\
\hline $\begin{array}{l}\text { ENTREPRE- } \\
\text { NEURS }\end{array}$ & 12 & $\begin{array}{c}10 \text { men } \\
2 \text { women }\end{array}$ & $\begin{array}{l}\text { Entrepreneurs from Burgos and its region in: informatics consultant, lan- } \\
\text { guage teaching, new technologies, building, energetic consultant, grapho- } \\
\text { logy, photography, energetic efficiency, engineering, oenology and occupa- } \\
\text { tional therapy. }\end{array}$ \\
\hline $\begin{array}{l}\text { EXPERTS AND } \\
\text { TECHNICAL }\end{array}$ & 10 & $\begin{array}{l}5 \text { womwn } \\
5 \text { men }\end{array}$ & $\begin{array}{l}\text { Representatives from: Cámara de Comercio, FAE (Confederación de Aso- } \\
\text { ciaciones Empresariales de Burgos), FEC (Federación de Empresarios de } \\
\text { Comercio), Área de Juventud del Ayuntamiento de Burgos, Unidad de } \\
\text { Empleo de la Universidad de Burgos, AJE (Asociación de Jóvenes Empre- } \\
\text { sarios), CEEI (Centro Europeo de Empresas e Innovación de Burgos), Di- } \\
\text { rección Territorial de la ADE (Agencia Desarrollo Económico) from Junta } \\
\text { de Castilla y León and SODEBUR (Sociedad para el Desarrollo de la Pro- } \\
\text { vincia de Burgos) of Diputación de Burgos }\end{array}$ \\
\hline EDUCATORS & 3 & $\begin{array}{l}2 \text { men } \\
1 \text { woman }\end{array}$ & Career advisers from the IES de Burgos, Lerma and Miranda de Ebro \\
\hline
\end{tabular}

vista grupal o Grupo de Discusión útil para obtener información de los participantes de forma semiestructurada, cuya finalidad es provocar un debate intenso entre las personas representantes que forman parte del GD (Ramos Sánchez, 2011).

La incorporación de esta técnica tiene como objetivo identificar los principales problemas relacionados con el emprendimiento, conocer el punto de vista y los intereses de los distintos colectivos y rea- yed as an useful technique to obtain participants' information in a semi-structured way, whose purpose is to provoke an intense debate among people representatives who are part of the DG (Ramos Sánchez, 2011).

The incorporation of this technique aims to identify the main problems related to entrepreneurship, to be aware of the different groups point of view and interests and to perform a prospective appro- 
lizar una aproximación prospectiva sobre las tendencias a medio y largo plazo en relación con el emprendimiento.

En este estudio se llevaron a cabo tres GD con distintos sectores relacionados con el emprendimiento. En concreto; con agentes de la comunidad educativa, agentes sociales y económicos y jóvenes emprendedores.

En este artículo se presenta el make-of de los tres Grupos de Discusión y el posterior análisis descriptivo de las aportaciones realizadas en dichos grupos.

\subsection{Análisis de los Datos}

Para el análisis cualitativo de las aportaciones de los Grupos de Discusión se ha utilizado el software NVivo9.

\subsection{Procedimiento}

La finalidad de los tres GD que se llevaron a cabo fue analizar las necesidades y expectativas de los jóvenes en relación con la red de emprendimiento, conocer las políticas aplicadas al emprendimiento, las ayudas existentes y si el sistema educativo está favoreciendo el emprendimiento. Igualmente se indaga sobre las necesidades a nivel político, a nivel económico y en el ámbito educativo-formativo del emprendimiento juvenil.

Como ya hemos señalado, estos grupos de discusión se dividieron en tres grupos focales; el grupo de orientadores-educadores, el de emprendedores y el grupo de expertos.

A continuación, se relata el proceso seguido (Making-of) con dichos GD. A principios del mes de febrero de 2013, el equipo de investigación planteó la configuración de los GD y la metodología a aplicar en los mismos. Posteriormente, se trabajó sobre las preguntas concretas que se utilizarían en cada uno de ellos y que servirían de guion para dirigirles y para dinamizar el debate. Una vez establecidas las cuestiones y preguntas a debatir de interés para nuestros objetivos las agrupamos, analizando de esta forma en los tres GD: las necesidades en general del emprendedor, las necesidades formativas del emprendedor y las expectativas de los emprendedores.

El documento final con las preguntas a tratar en ach on medium and long-term trends related to entrepreneurship.

In this research, three DG were developed in different sectors related to entrepreneurship. In this research, three DG were developed in different sectors related to entrepreneurship. In particular they are agents from the educational community, social and economic agents, and young entrepreneurs.

The paper presents a making-of of the three Discussion Groups and the final descriptive analysis and their contributions.

\subsection{Data analysis}

For the qualitative analysis of the contributions of the group discussion (hereinafter DG) the NVivo9 software has been used.

\subsection{Procedure.}

The purpose of the three developed DG discussion groups was to analyse the young people's needs and expectations in relation to the entrepreneurship network, to learn the policies applied to the entrepreneurship, the existing aids and to check if the educational system is encouraging entrepreneurship. It also explores the needs at a political and economical level, and in the educational-formative area of youth entrepreneurship.

As we have already pointed out, these discussion groups were divided into three focus groups; the advisers-educators, entrepreneurs and the group of experts.

The followed process (Making-of) with such GD is presented bellow. At the beginning of February 2013, the research team raised the DG configuration and methodology to apply on them. Subsequently, we worked on the specific questions that would be used in each of them and that would serve as a script to guide them and to stimulate the debate. Once the relevant issues and questions for discussion are established, we grouped them, analysing in the three DG: the general needs of the entrepreneur, their training needs and their expectations.

The final document with the questions to be addressed at each of the discussion groups was called 
cada uno de los grupos de discusión lo denominados Esquema del Grupo de Discusión y se presenta en el Apéndice 1.

Estas cuestiones además de debatirse se recogerían por escrito por parte de cada uno de los participantes. Por otro lado se estableció el número adecuado de participantes; entre 8 y 12 por grupo y la duración de los GD; máximo de dos horas, tal y como recomiendan León y Montero (2012). Aspecto que se cumplió excepto en el GD de educadores y orientadores.

De forma paralela, se plantearon las posibles fechas de celebración, la ubicación y las personas a las que se cursaría invitación. En cuanto a los posibles participantes se planteó un listado por grupo de discusión focal. El procedimiento de contacto fue en un primer momento mediante llamada de teléfono, realizado durante el mes de marzo de 2013. Cuando el participante confirmaba telefónicamente su asistencia se le cursaba invitación oficial y se le adjuntaba el listado de preguntas (Esquema del Grupo de Discusión) para que tuviesen un guion del mismo y a su vez pudieran ir cumplimentando las cuestiones que se iban a tratar, tal y como establecen León y Montero (2012).

La última quincena de marzo y la primera de abril de 2013 se destinó a preparar la logística que conllevaban los GD. En cuanto a las consideraciones metodológicas se tuvo en cuenta lo planteado por Ramón Sánchez (2011) y León y Montero (2012) en lo referente a los moderadores y participantes de las sesiones y el registro de las sesiones que en nuestro estudio fue a través de recursos tecnológicos de audio y vídeo además de las notas manuscritas.

El procedimiento de actuación de acuerdo con Ramón Sánchez (2011) tuvo tres fases, la preparación de la sesión, el desarrollo de la sesión y el análisis e interpretación del discurso del grupo.

En cuanto al desarrollo de las sesiones destacamos algunos de los aspectos más relevantes: Acogida de cada participante y firma de la Autorización de Cesión de los Derechos de Imagen explicándoles que la sesión sería grabada; Presentación breve de la IP (Investigadora Principal) sobre el objetivo del proyecto de investigación y de los grupos de discusión; Ronda de presentación antes de entrar a discutir las preguntas; Información de las instrucciones de participación, por parte de dos miembros del
Scheme of the Discussion Group and is presented in Appendix 1.

These issues, apart from being discussed, are written down by each participant. On the other hand, the accurate number of participants was established; between 8 and 12 per group; and the duration of the DG; maximum of two hours, as recommended by León and Montero (2012). This aspect appears in all groups excepting in the DG of educators and career advisers.

At the same time, the possible dates for celebration, location and people that will attend the invitation increased. In terms of potential participants a listing by focal discussion group was raised. The contact procedure was through phone call initially, made during the month of March 2013. When the participant confirmed his/her assistance by phone an official invitation was sent with a list of questions (Discussion Group Scheme) so they had a script of it and at the same time they could fill in the issues that were going to be treated, as established by León and Montero (2012).

The last half of March and the first of April 2013 was devoted to prepare the DG's logistics. In terms of the methodological considerations it was took into account the issues raised by Ramón Sánchez (2011) and León and Montero (2012) in relation to the moderators and session participants and the registration of the sessions that was made through technological resources audio and video as well as handwritten notes. in our research.

The action plan according with Ramón Sánchez (2011) had three phases, the preparation of the session, the development of the session and the analysis and interpretation of the speech of the group.

In terms of the development of the sessions some of the most relevant aspects are: Reception of each participant and signing of the Authorization of Assignment of the Rights of Image explaining that the session could be recorded; Brief presentation of the MR (Main Researcher) about the project aim of research and discussion groups; Presentation round before discussing questions; Information on the participation instructions by two members of the research group which, in turn, conducted the speaking time; the participation time was limited to the two-hour planned for each 
Tabla 2. Categorías y subcategorías por Grupos de Discusión

\section{CATEGORÍA SUBCATEGORÍA}

EM EXEX EDED

\begin{tabular}{|c|c|c|c|c|}
\hline $\begin{array}{l}\text { C1: Definición de } \\
\text { emprendimiento }\end{array}$ & $\begin{array}{l}\text { Compromiso y dedicación; Forma y/o proyecto de vida; Difícil y soli- } \\
\text { taria; Gratificante; Vocación; Solución de problemas desde visión di- } \\
\text { ferente; Ilusión/pasión; Paciencia/ perseverancia; Riesgo; Reto }\end{array}$ & $x$ & & $X$ \\
\hline $\begin{array}{l}\text { C2: Motivos para } \\
\text { emprender }\end{array}$ & $\begin{array}{l}\text { Necesidad laboral; Orgullo/Moda; Vocación; Cultura generacional } \\
\text { empresarial; Por desesperación; Para realizar el trabajo deseado }\end{array}$ & $x$ & $x$ & $x$ \\
\hline $\begin{array}{l}\text { C3: Ayudas eco- } \\
\text { nómicas }\end{array}$ & $\begin{array}{l}\text { INEM/ ECYL; JCYL-ADE; Ayuntamiento; Ninguna; Propia- familiar; } \\
\text { Ministerio de Economía/ ICO; Diputación; Iberaval }\end{array}$ & $x$ & $X$ & $x$ \\
\hline $\begin{array}{l}\text { C4: Formación ne- } \\
\text { cesitada para } \\
\text { crear empresa }\end{array}$ & $\begin{array}{l}\text { Conocimientos Técnicos; Conocimientos legales; Conocimientos } \\
\text { comerciales; Nuevas Tecnologías; Conocimientos transversales au- } \\
\text { toempleo; Conocimientos de gestión de empresas; Idiomas }\end{array}$ & $X$ & $X$ & $X$ \\
\hline $\begin{array}{l}\text { C5: Formación a } \\
\text { incorporar a ESO } \\
\text { y FP }\end{array}$ & $\begin{array}{l}\text { Conocimientos técnicos; Prácticas reales; Conocimientos de legisla- } \\
\text { ción; Conocimientos transversales autoempleo; Nuevas tecnologías; } \\
\text { Conocimientos comerciales; Conocimientos de gestión de empre- } \\
\text { sas; Ninguna }\end{array}$ & $x$ & $x$ & $X$ \\
\hline $\begin{array}{l}\text { C6: Competen- } \\
\text { cias y habilidades } \\
\text { útiles }\end{array}$ & $\begin{array}{l}\text { Habilidades sociales; Comunicación; Liderazgo; Adaptación a los } \\
\text { cambios; Perseverancia- capacidad de trabajo; Sentido común; Asu- } \\
\text { mir riesgos calculados; Responsabilidad; Trabajo en equipo; Imagina- } \\
\text { ción y creatividad; Iniciativa; Otras }\end{array}$ & $x$ & $X$ & $X$ \\
\hline $\begin{array}{l}\text { C7: Conoce o ha } \\
\text { desarrollado re- } \\
\text { des formales }\end{array}$ & $\begin{array}{l}\text { Iniciador Burgos; Proyecto Yuzz Burgos; AJE; StartupWeekend; } \\
\text { TedxBurgos; NetworkingBur; TECHDAY6o; Iredes; ContuberbioSo- } \\
\text { cialMedia; El Fid; ADE2O; Otras }\end{array}$ & $x$ & $X$ & \\
\hline $\begin{array}{l}\text { C8: Dificultades / } \\
\text { Demandas encon- } \\
\text { tradas para ser } \\
\text { emprendedor }\end{array}$ & $\begin{array}{l}\text { Falta de conocimientos transversales de emprendimiento; Falta de } \\
\text { conocimientos comerciales; Financiación; Vender el proyecto a } \\
\text { clientes; Falta de visión global de empresa; Burocracia; Otros; For- } \\
\text { mación gratuita en gestión de empresas; Carga fiscal; Exención de } \\
\text { impuestos; Facilidad contratar familiares }\end{array}$ & $x$ & $X$ & \\
\hline $\begin{array}{l}\text { C9: Asignatura } \\
\text { más valiosa }\end{array}$ & $\begin{array}{l}\text { Contabilidad; Análisis de coste; Fiscal; Asignaturas financieras; Ofi- } \\
\text { mática; Cursos de formación no reglados; Ninguna; Asignaturas Téc- } \\
\text { nicas; Marketing- Empresa; FOL }\end{array}$ & $X$ & & \\
\hline $\begin{array}{l}\text { C 10: Nivel educa- } \\
\text { tivo en los que ad- } \\
\text { quirir competencias }\end{array}$ & $\begin{array}{l}\text { Infantil- Primaria; Últimos años de FP; Último año universidad; En to- } \\
\text { dos los niveles educativos; Secundaria; Bachillerato }\end{array}$ & & $x$ & $x$ \\
\hline $\begin{array}{l}\text { C 11: Organismos } \\
\text { que asesoran }\end{array}$ & $\begin{array}{l}\text { JCYL- ADE; AJE; Universidad; Ayuntamiento; Cámara de comercio; } \\
\text { ICEX; Diputación; CEEl }\end{array}$ & & & $x$ \\
\hline $\begin{array}{l}\text { C 12: Coordina- } \\
\text { ción entre organis- } \\
\text { mos }\end{array}$ & $\begin{array}{l}\text { No hay; Se dan esfuerzos duplicados; No es suficiente; Hay deriva- } \\
\text { ción entre organismos }\end{array}$ & & $x$ & $x$ \\
\hline $\begin{array}{l}\text { C 13: Sectores } \\
\text { atractivos }\end{array}$ & $\begin{array}{l}\text { Nuevas tecnologías; Energético; Primario; Telecomunicaciones; Ser- } \\
\text { vicios; Ocio; Infancia; Social; Ninguno; Biotecnología; Turismo; Cul- } \\
\text { tura }\end{array}$ & $x$ & & \\
\hline $\begin{array}{l}\text { C 14: Competen- } \\
\text { cias de inicio }\end{array}$ & $\begin{array}{l}\text { Energía- pasión- ilusión; Confianza en sí mismo; Planificación- organi- } \\
\text { zación; Sentido común -responsabilidad; Habilidades sociales; Opti- } \\
\text { mismo; }\end{array}$ & $X$ & & \\
\hline $\begin{array}{l}\text { C 15: Competen- } \\
\text { cias desarrolladas }\end{array}$ & $\begin{array}{l}\text { Paciencia; Adaptación a los cambios; Liderazgo; Habilidades sociales } \\
\text { y comerciales; Toma de decisiones; Delegar; Negociar; Venta; Crea- } \\
\text { tividad; Eficacia }\end{array}$ & $X$ & & \\
\hline
\end{tabular}


Table 2. Categories and subcategories for Discussion Groups

\section{CATEGORIES SUBCATEGORIES}

EM EXEX ED ED

\begin{tabular}{lll}
\hline $\begin{array}{l}\text { C1: Definition of } \\
\text { entrepreneurship }\end{array}$ & $\begin{array}{l}\text { Compromise and dedication; way of life/life Project; Difficult and so- } \\
\text { lidary; Gratifying; Vocation; Problem solving from a different vision; } \\
\text { Dream/passion; Patience/perseverance; Risk; Challenge }\end{array}$ & $X$ \\
\hline $\begin{array}{l}\text { C2: Motivation to } \\
\text { start a business }\end{array}$ & $\begin{array}{l}\text { Necessity of a job; Pride/Fashion; Vocation; Generational business } \\
\text { culture; by desperation; to perform the dreamed job }\end{array}$ & $X$ \\
\hline $\begin{array}{l}\text { C3: Economic } \\
\text { aids }\end{array}$ & INEM/ ECYL; JCYL-ADE; Town-Hall; None; Oneself- familiar; Mi- & $X$ \\
\hline $\begin{array}{l}\text { C4: Needed edu- } \\
\text { cation to start a } \\
\text { business }\end{array}$ & $\begin{array}{l}\text { Technical knowledge; Legal knowledge; Commercial knowledge; } \\
\text { ness management knwoledge; languages }\end{array}$ & $X$ \\
\hline $\begin{array}{l}\text { C5: Formation } \\
\text { and education to } \\
\text { add to GCSE/PE }\end{array}$ & $\begin{array}{l}\text { Technical knowledge; Real internships; Legal knowledge; Cross-cut- } \\
\text { ting self-employment knowledge; New Technologies; Commercial } \\
\text { knowledge; Business management knowledge; None }\end{array}$ & $X$ \\
\hline $\begin{array}{l}\text { C6: Useful compe- } \\
\text { tences and abili- } \\
\text { ties }\end{array}$ & $\begin{array}{l}\text { Social abilities; Communication; Leadership; Adaptation to changes; } \\
\text { Perseverance- ability to work; Common sense; Assume calculated } \\
\text { risks; Responsibility; Team work; Imagination and creativity; Initiative; } \\
\text { Others }\end{array}$ & $X$ \\
\hline $\begin{array}{l}\text { C7: Know or has } \\
\text { developed formal } \\
\text { networks }\end{array}$ & $\begin{array}{l}\text { Inicador Burgos; Proyecto Yuzz Burgos; AJE; StartupWeekend; } \\
\text { cialMedia; El Fid; ADE2O; Others }\end{array}$ & $X$ \\
\hline
\end{tabular}

C8:

Difficulties/Demands found to Lack of cross-cutting self-employment knowledge; Lack of commerstart a business cial knowledge; Financing; Sell the project to clients; Lack of business global vision; Bureaucracy; Others; Free education in business $X \quad X$

C9: Most valued subjects

Accountability; Cost analysis; Fiscal; Finance subjects; Office IT; Non-official training courses; None; Technical Subjects; MarketingBusiness; FOL

C 10: Educative level for acquire competences

Pre-School-Primary; Last courses of PE; Last year at UNI; At all educative levels; Secondary, A-Levels

C 11: Supportive organizations

JCYL- ADE; AJE; University; Town-Hall; Cámara de comercio; ICEX; Regional government; CEEl

C 12: Coordination
among administra-
tions

There are not; Doubled efforts; It's not enough; There's derivation between organizations

\section{$x$}

Compromise and dedication; way of life/life Project; Difficult and so-
lidary; Gratifying; Vocation; Problem solving from a different vision;
Dream/passion; Patience/perseverance; Risk; Challenge $\quad$ X

\section{-}


grupo de investigación que a su vez dieron el turno de palabra; Se limitó el tiempo de participación para ajustarse estrictamente a las dos horas de duración previstas para cada grupo, por lo que a las dos horas de debate, la IP cerraba los grupos de discusión planteando un resumen de lo tratado.

Aproximadamente a los dos días de la celebración se envió a cada uno de los participantes un correo de agradecimiento.

Toda la información y material bruto se recogió y almacenó, según los consejos recogidos en León y Montero (2012) para posteriormente poder realizar el análisis de los datos cualitativos de este estudio.

\section{Resultado}

En el análisis de las aportaciones se parte del marco general teórico aportado en la justificación para establecer la categorización deductiva (Pérez, 2000; Quecedo \& Castaño, 2003; Valdemoros, et al., 2011), estableciéndose así categorías validadas por el juicio de tres expertos en el ámbito del emprendimiento y la educación. Por otro lado, a través del análisis textual, se procedió a alojar las unidades textuales en cada uno de los nodos creados por las categorías, dando lugar a las subcategorías.

En función de los resultados se han establecido 15 categorías conformadas por subcategorías que tienen su aplicación a los tres grupos de discusión: Emprendedores (EM), Expertos (EX) y Educadores y Orientadores (ED) tal y como se muestra en la Tabla 2.

\subsection{Resultados por categorías}

A continuación mostramos los resultados obtenidos por cada grupo de discusión dentro de las categorías y subcategorías establecidas que mayores referencias textuales han recibido, siendo los datos aportados los porcentajes de respuesta en cada GD por cada una de las unidades textuales de las subcategorías en la codificación descriptiva. Para la realización de los gráficos se ha utilizado el programa Excel con los datos aportados por el programa de análisis cualitavo Nvivo.

En el porcentaje de respuesta de la categoría 1 ( $\mathrm{C}_{1}$ ) (Figura 1), referida a la expresión de aspectos relevantes en la definición de emprendimiento, po- group, so after those two hours of debate, the MR closed the discussion groups posing a summary of discussions.

Approximately two days after all participants received a gratitude email.

All information and raw material was collected and stored according to the tips from León and Montero (2012) to subsequently perform this study's quantitative data analysis.

\section{Results}

The analysis of the contributions started from the general theoretical framework provided in the justification for establishing the deductive categorization (Pérez, 2000; Quecedo \& Castaño, 2003; Valdemoros, et al., 2011), thus establishing categories validated by three experts in the field of entrepreneurship and education. On the other hand, through textual analysis, the units were allocated into the created categories, leading to the subcategories.

Depending on the results, 15 categories composed of subcategories with application to the three discussion groups have been established: Entrepreneurs (EM), experts (EX) and Educators and Career advisers (ED) as shown in Table 2.

\subsection{Results by category}

The results obtained by each discussion group within the established categories and sub-categories with further textual references (being the provided data the percentages of response of each DG for each of the subcategories in the descriptive encoding textual units) are exposed bellow. For the graphics, an Excel sheet was created with data provided by the program of qualitative analysis Nvivo.

The percentage of response from category 1 (C1) (Figure 1), referred to the expression of relevant aspects in the definition of entrepre- 
Figura 1. Porcentajes de respuesta en C1 Definición de 'emprendimiento'

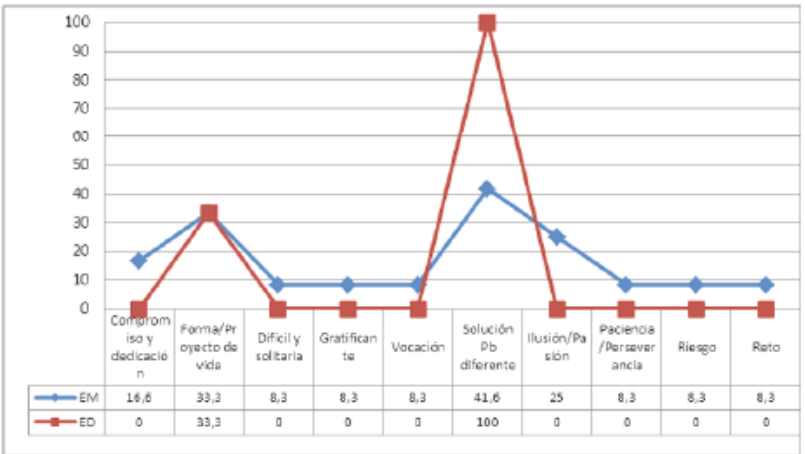

Fuente: Elaboración propia.

Figura 2. Porcentajes de respuesta en $\mathrm{C}_{2}$ Motivos para emprender

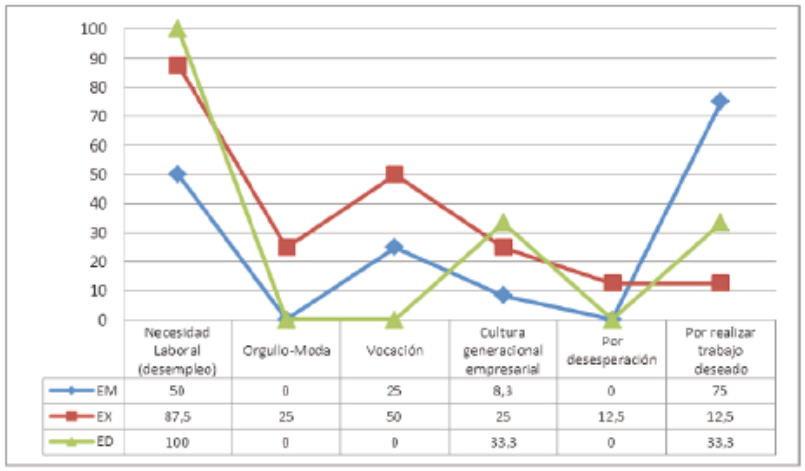

Fuente: Elaboración propia.

demos destacar que los emprendedores muestran en primer lugar el emprendimiento como vía de solución de problemas desde un punto de vista diferente, con un $41,6 \%$ de tasa de respuesta. En segundo lugar, como una forma de ser y proyecto de vida con un $33,3 \%$, como ilusión y pasión con un $25 \%$ y como compromiso y dedicación con un $16,6 \%$. Tras estas subcategorías encontramos que el resto permanecen con una tasa de respuesta de $8,3 \%$.

En el caso del GD de educadores y orientadores muestran unanimidad al señalar la subcategoría de solución a los problemas desde un punto de vista diferente como aspecto más relevante de la definición de emprendimiento. En segundo lugar, se señala la subcategoría como una forma o proyecto de vida con un $33,3 \%$ de respuesta. El resto de subcategorías no encuentran respuesta dentro del GD.

En la Figura 2 podemos observar los porcentajes de respuesta de la categoría 2 referida a los motivos por lo que crear empresa. En él observamos que los emprendedores muestran tasas de respuesta en la motivación relacionadas con realizar el
Figure 1. Percentages of answer for $\mathrm{C} 1$ Definition of 'entrepreneurship'

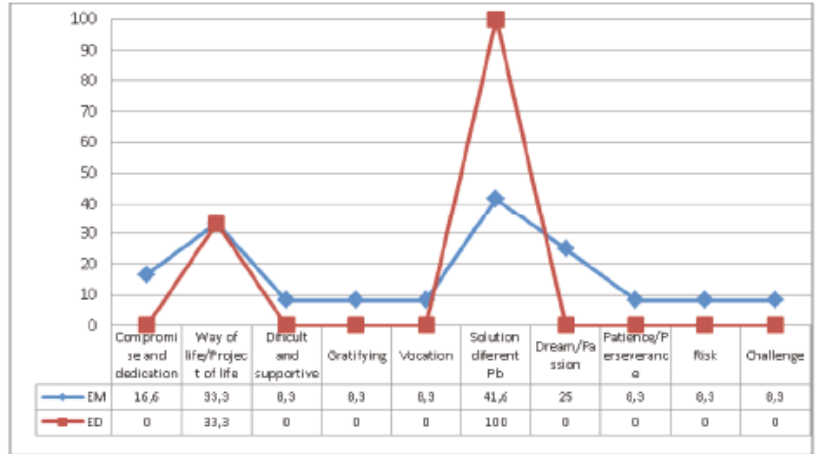

Source: Personal compilation.

Figure 2. Response percentages for $\mathrm{C}_{2}$ Reasons to start a new business

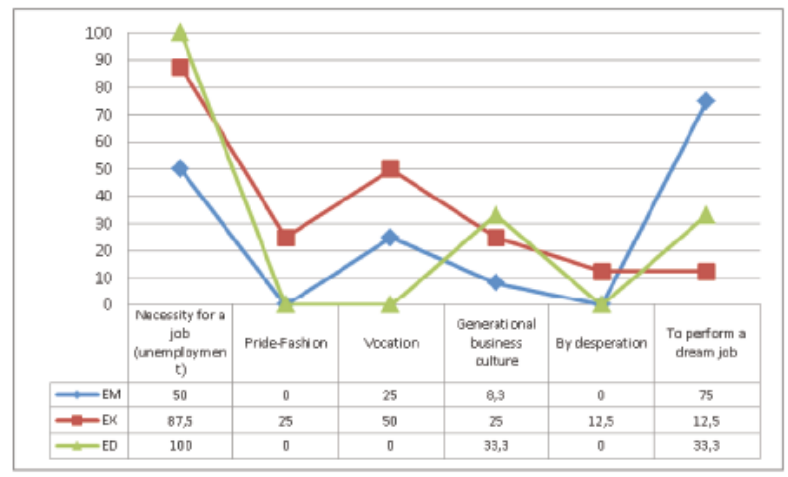

Source: Personal compilation.

neurship, we can highlight that entrepreneurs firstly show entrepreneurship as a way of solving problems from a different point of view, with a response rate of $41.6 \%$. Secondly, as way of being and life project $(33.3 \%)$, enthusiasm and passion (25\%) and as commitment and dedication (16.6\%). After these subcategories, we find that the rest remain with a response rate of $8.3 \%$.

In the case of the DG of educators and career advisers there is unanimity in pointing out the subcategory's "solution to problems from a different point of view" as the most relevant aspect of the definition of entrepreneurship. Secondly, a 33.3\% refers to the subcategory as a way or life or project. The rest of the subcategories do not find response within the DG.

In Figure 2 we can see the percentages of response for category 2 referred to the reasons to create company. We can see that entrepreneurs motivation response' rates are related to the desired of work $(75 \%)$, the need for a job $(50 \%)$, by vocation $(25 \%)$ and for a generational 
Figura 3. Porcentajes de respuesta en $\mathrm{C} 3$ Ayudas económicas

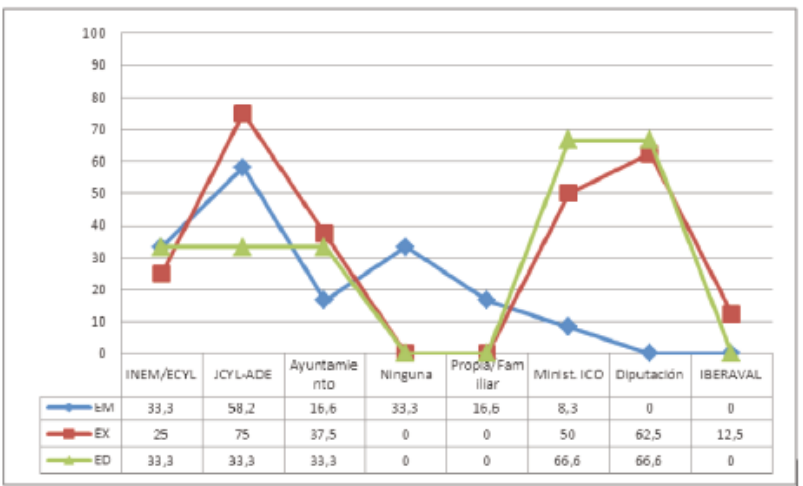

Fuente: Elaboración propia.

trabajo deseado (75\%), como necesidad laboral $(50 \%)$, por vocación $(25 \%)$ y por cultura generacional empresarial ( $8,3 \%)$, no obteniendo respuesta las motivaciones relacionadas con la moda o por desesperación.

En el caso de los expertos las tasas de respuesta sobre las motivaciones para ser emprendedor se sitúan en primer lugar la necesidad laboral (87,5\%), seguidas de la vocación (50\%), moda y cultura generacional $(25 \%)$ y por desesperación y realizar el trabajo deseado (12,5\%). Los educadores muestran unanimidad en la motivación relacionada con la necesidad laboral (100\%), seguidas de la cultura generacional y por realizar el trabajo deseado (33,3\%), no obteniendo respuesta para la moda y por desesperación.

En el porcentaje de respuesta de la categoría 3 referida a las ayudas económicas que se conocen destinadas al emprendimiento (Figura 3), dentro del grupo de emprendedores no se encuentran tasas de respuesta superiores al $60 \%$ siendo las de mayor respuesta: JCYL-ADE (58,2\%), INEM-ECYL y Ninguna (33,3\%), Ayuntamiento y propia familia (16,6\%) y el Ministerio-ICO (8,3\%). Tanto Diputación como IBERAVAL no han tenido respuesta.

Dentro del grupo de expertos las ayudas económicas hacia el emprendimiento tienen mayor frecuencia las referidas a JCYL-ADE (75\%), Diputación (62,5\%) y Ministerio-ICO (50\%), situándose por debajo del $50 \%$ de tasa de respuesta el Ayuntamiento (37,5\%), INEM-ECYL (25\%) e IBERAVAL (12,5\%), no obtienen respuesta la propia familia y ninguna ayuda. Por otro lado, los educadores y orientadores muestran mayor respuesta en Ministerio-ICO y Diputación (66,6\%), siendo menor en el caso de
Figure 3. Percentage of response for $\mathrm{C} 3$ Economic aids

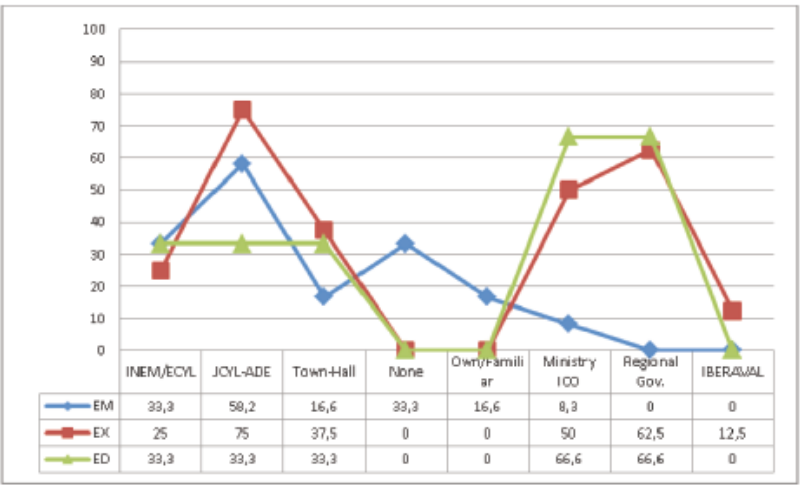

Source: Personal compilation.

business culture (8.3\%), not getting any response motivations related to fashion or by desperation.

In the case of experts, their responses rates about the motivations for being an entrepreneur are firstly the need for a job (87.5\%), followed by the vocation (50\%), fashion and generational culture $(25 \%)$ and by despair and to perform the desired work (12.5\%). Educators show unanimity on motivation related to the need for a job (100\%), followed by the generational culture and to perform the desired work $(33.3 \%)$, not getting any response at all to do so by fashion and despair.

The percentage of response for category 3 concerning economic subsidies aimed to entrepreneurs (Figure 3), within the group of entrepreneurs there are no response rates exceeding $60 \%$ being the largest response: JCYL-ADE (58.2\%), INEM-ECYL and none (33.3\%), Town Hall and own family $(16.6 \%)$ and the Ministry-ICO (8.3\%). Both the Local Government and IBERAVAL have given no response.

Within the experts group the aid towards entrepreneurship are more frequent concerning JCYL-ADE (75\%), Provincial government (62.5\%) and Ministry-ICO (50\%), having less than $50 \%$ issues such as Town-Hall (37.5\%), INEM-ECYL (25\%) and IBERAVAL (12.5\%), don't get response the family and no support. On the other hand, educators and career advisers show a greater response in Ministry-ICO and Provincial Government $(66.6 \%)$, being lower in the case of INEM-ECYL, JCYL-ADE and Town Hall (33.3\%), having no response IBERAVAL, Family supports, 
Figura 4. Porcentajes de respuesta en $\mathrm{C}_{4}$ Formación necesaria para emprender

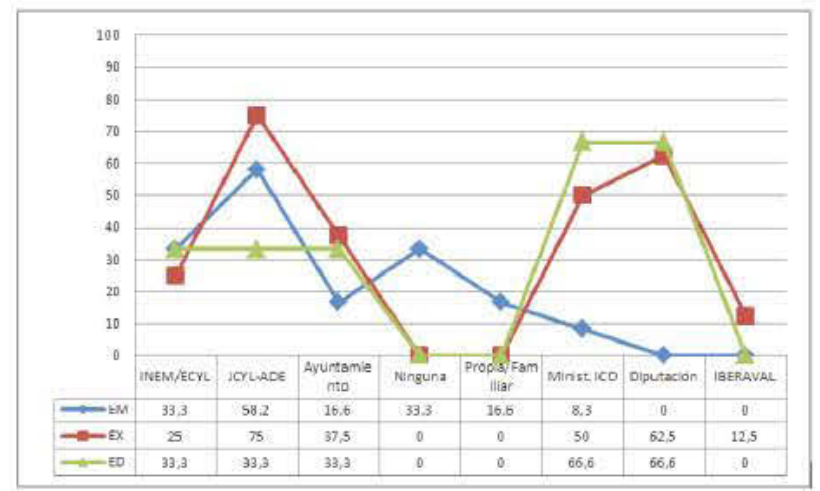

Fuente: Elaboración propia.

Figura 5. Porcentajes de respuesta en $\mathrm{C}_{5}$ Formación y conocimientos a incorporar en ESO y FP

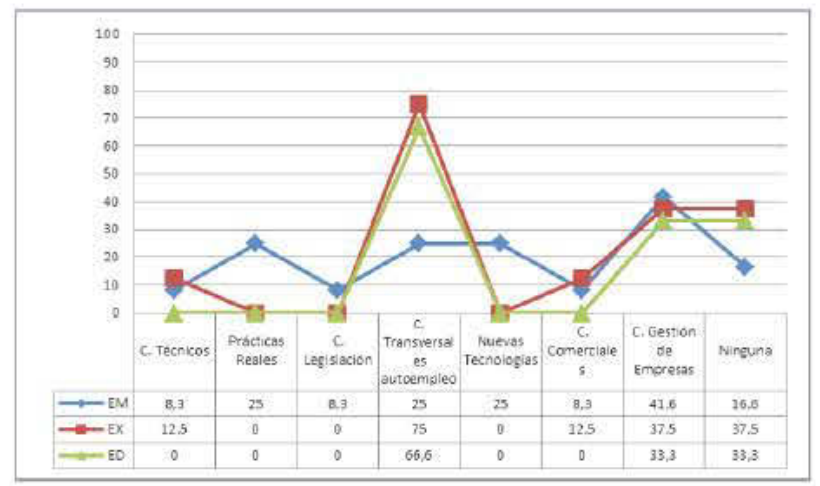

Fuente: Elaboración propia.

INEM-ECYL, JCYL-ADE y Ayuntamiento (33,3\%), no teniendo respuesta IBERAVAL, Ayudas familiares y Ninguna ayuda.

Dentro de la categoría $\mathrm{C}_{4}$ (Figura 4) sobre los conocimientos necesarios para emprender, el GD formado por emprendedores obtienen mayores porcentajes de respuesta en Conocimientos de gestión de empresas (50\%) y Conocimientos técnicos $(41,6 \%)$, tras ellos encontramos las nuevas tecnologías (33,3\%), Conocimientos transversales sobre autoempleo (25\%), Conocimientos legales $(25 \%)$ y Conocimientos comerciales. El porcentaje menor de respuesta es el de Idiomas ( $8,3 \%)$.

Los expertos muestran mayor tasa de respuesta en los Conocimientos técnicos y Transversales de Autoempleo (75\%), obteniendo menores puntuaciones los conocimientos de Gestión de empresas (37,5\%) y Comerciales (25\%). En este GD no han obtenido ninguna referencia textual los Idiomas, las Nuevas Tecnologías y los conocimientos legales. Los Educadores y Orientadores muestran mayores re-
Figure 4. Response percentages for $\mathrm{C}_{4}$ Necessary training to start a new business

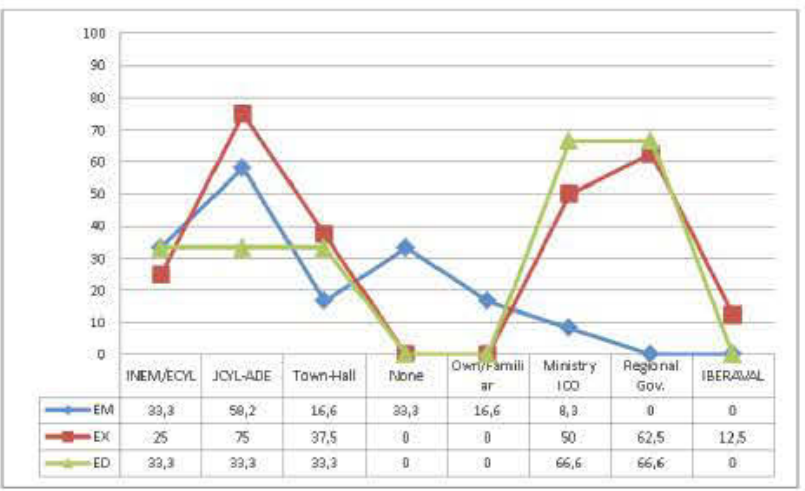

Source: Personal compilation.

Figure 5. Percentage of response for $\mathrm{C}_{5}$ Training and knowledge to incorporate into GCSE and PE

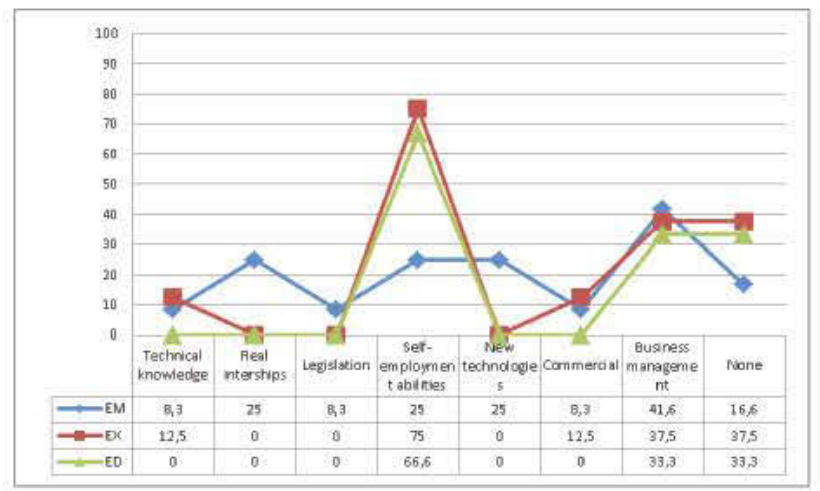

Source: Personal compilation.

and No support.

In the category $\mathrm{C}_{4}$ (Figure 4 ) about the necessary knowledge to start a business, in the entrepreneurs' DG the higher response answers were for Management of companies' abilities (50\%) and Technical knowledge (41.6\%), followed by New technologies (33.3\%), Transversal knowledge on self-employment ( $25 \%)$, Legal knowledge $(25 \%)$ and Commercial knowledge. The lower percentage was for Languages ( $8.3 \%$ )

The experts show a higher response rate for Technical and Cross-cutting Knowledge on selfemployment (75\%), getting lower rates for Companies management $(37.5 \%)$ and Commercial (25\%). In this DG languages, new technologies and the legal knowledge have not obtained any textual reference. Educators and career advisers show further references to knowledge of companies' management (66.6\%), with lower rates for Technical and Transversal's self-employment knowledge (33.3\%). The 
Figura 6. Porcentajes de respuesta en C6 Competencias y habilidades útiles para el emprendimiento

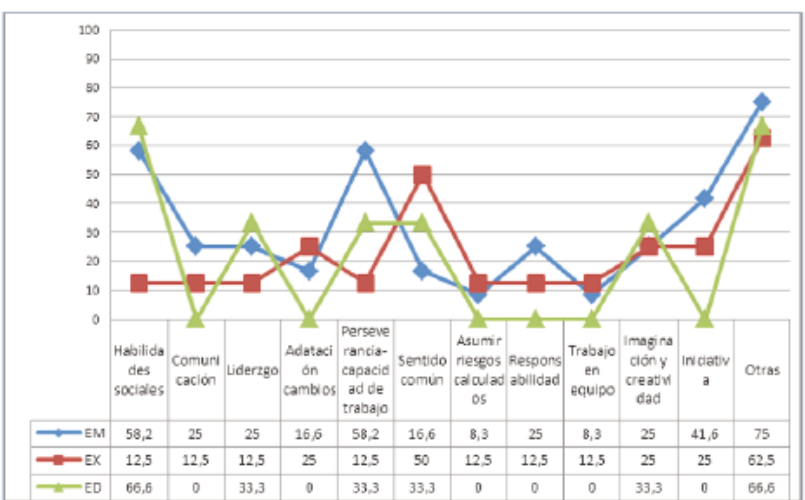

Fuente: Elaboración propia.

ferencias hacia los conocimientos de gestión de empresas $(66,6 \%)$, siendo menor las puntuaciones de Conocimientos técnicos y Transversales de Autoempleo (33,3\%). No obtienen menciones las subcategorías de Conocimientos legales, Comerciales, Nuevas Tecnologías e Idiomas.

Dentro del GD de emprendedores, en referencia a la categoría 5 (Figura 5) sobre la formación y conocimientos a incorporar en la ESO y FP, muestran mayores porcentajes de respuesta los conocimientos relacionados con la Gestión de Empresas (41,6\%), así como Prácticas reales, Conocimientos transversales de autoempleo y Nuevas tecnologías (25\%). Las subcategorías con menores porcentajes de respuesta son los Conocimientos técnicos, de Legislación y Comerciales (8,3\%).

Los expertos muestran mayores alusiones a las Competencias transversales sobre autoempleo (75\%), con menores porcentajes encontramos Conocimientos de Gestión de empresas (37,5\%), Conocimientos Técnicos (12,5\%) y Comerciales (12,5\%). Los conocimientos de legislación, Nuevas Tecnologías y Prácticas reales no han encontrado menciones por parte de este grupo. Los educadores muestran mayores referencias en los Conocimientos Transversales de autoempleo (66,6\%), siendo menores las referencias a los conocimientos de Gestión de Empresas $(33,3 \%)$, el resto de subcategorías no obtienen referencias.

De las subcategorías establecidas para la categoría 6 (Figura 6) sobre las competencias y habilidades útiles para el emprendimiento, el GD de emprendedores muestran mayores referencias a las Habilidades sociales, Perseverancia y capacidad de trabajo $(58,2 \%)$ así como la Iniciativa $(41,6 \%)$, con me-
Figure 6. Percentage of response for C6 Useful competencies and skills for entrepreneurship

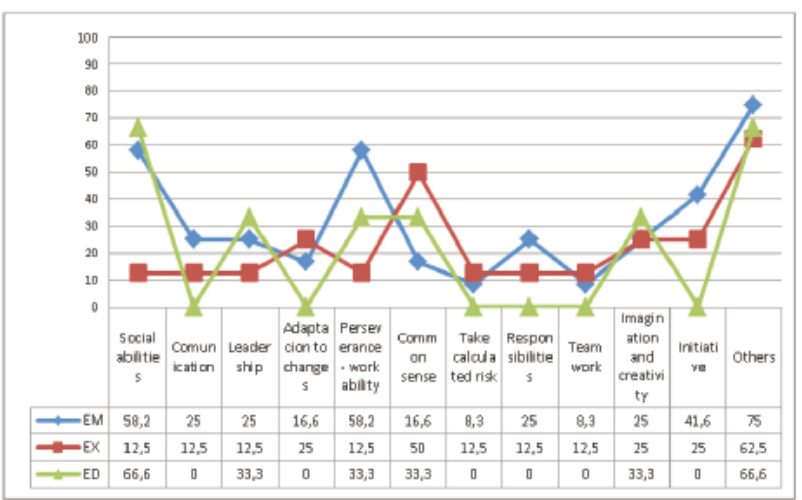

Source: Personal compilation.

subcategories of legal knowledge, commercial, New technologies and Languages are no mentioned.

Within the DG of entrepreneurs, regarding the category 5 (Figure 5) on training and expertise to incorporate in GCSE (General Certificate of Secondary Education) and $\mathrm{PE}$, show higher percentages of response the knowledge related to the Business management (41.6\%), as well as Current practices, Cross-cutting knowledge of New technologies (25\%) and self-employment. The subcategories with lower percentages are Technical knowledge, legislation and commercial (8.3\%).

Experts are more focused on skills as Self-employment (75\%), than on Business management (37.5\%), Technical (12.5\%) and Commercial (12.5\%). Knowledge of legislation, New technologies and Current practices were not mentioned by this group. Educators show further references on the cross-cutting knowledge of self-employment $(66.6 \%)$, being lower those to Business management (33.3\%), the rest of the subcategories don't get references.

Among the subcategories of category 6 ( $\mathrm{Fi}$ gure 6) on useful competencies and skills for entrepreneurship, the DG of entrepreneurs show higher references to social skills, perseverance and ability to work (58.2\%) as well as the initiative $(41.6 \%)$, with minor references for imagination and creativity, responsibility, leadership, and communication (25\%), being of lower contribution adaptation to changes (16.6\%), Common sense $(16.6 \%)$, Take calculated risks and Team work (8.3\%).

In the group of experts further references are 
Figura 7. Porcentajes de respuesta en $\mathrm{C} 7$ conoce $\mathrm{o}$ ha desarrollado redes formales de emprendimiento

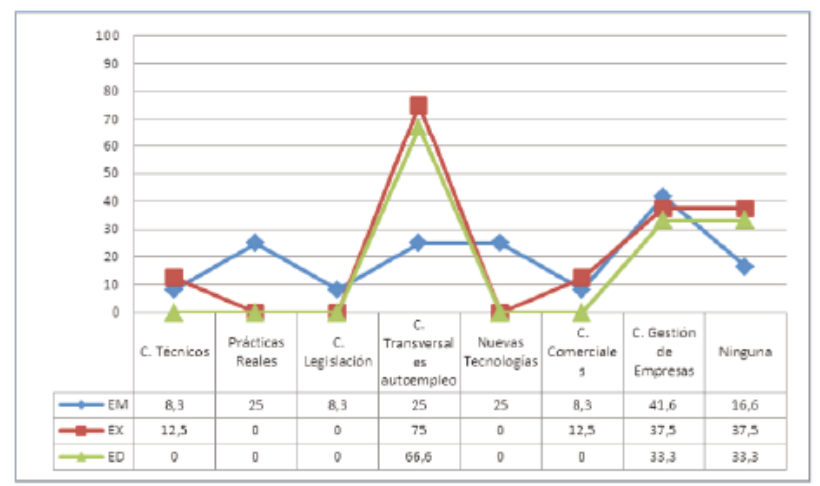

Fuente: Elaboración propia.

nores referencias se sitúan la Imaginación y creatividad, Responsabilidad, Liderazgo, y Comunicación (25\%), siendo las de menor aportación la Adaptación a los cambios (16,6\%), Sentido común (16,6\%), Asumir riesgos calculados y Trabajo en equipo (8,3\%).

En el grupo de expertos se expresan mayores referencias al Sentido común (50\%), seguido de Iniciativa, Imaginación y creatividad, Adaptación a los cambios (25\%), el resto de subcategorías muestran un $12,5 \%$ de respuesta. Para los educadores la competencia y habilidad más referenciada con un $66,6 \%$ son las Habilidades sociales, situándose con porcentajes del $33,3 \%$ las competencias de Liderazgo, Perseverancia y capacidad de trabajo, Sentido común e Imaginación y creatividad. El resto de subcategorías no obtienen respuesta.

Dentro de la C7 (figura 7) sobre el conocimiento o desarrollo de redes de emprendimiento formales, entendido como organizaciones compuestas por empresarios y/o organismos públicos cuyo objetivo es facilitar la conectividad y el intercambio de información (Herrera, 2009), podemos observar que las respuestas de los GD de emprendedores y expertos tienen tasas de respuesta diferentes, siendo mayores los porcentajes en los GD de Expertos que en los de Emprendedores, con la excepción de la AJE (Asociación de Jóvenes Empresario) en los que son mayores en los emprendedores y de StartupWeekend en el que se igualan ambos grupos (50\%).

En la figura 8 referida a la $\mathrm{C} 8$ en la que se recogen las tasas de respuesta dificultades y demandas para emprender, en las que el GD de empresarios muestra mayores porcentajes en las subcategorías de Burocracia $(50 \%)$ y financiación $(41,6 \%)$, mientras que
Figure 7. Percentage of response for $\mathrm{C}_{7}$ Knows or has developed formal networks of entrepreneurship

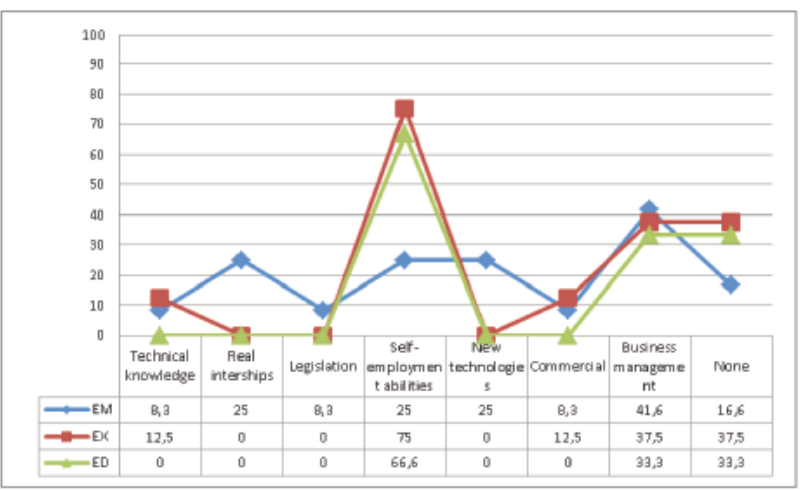

Source: Personal compilation.

expressed for common sense (50\%), followed by initiative, imagination and creativity, adaptation to changes (25\%), the rest of subcategories display a $12.5 \%$ response. For educators the more referenced competence and skill with a $66.6 \%$ are Social skills, and $33.3 \%$ for competencies such as Leadership, Perseverance and ability to work, Common sense and Imagination and creativity. The rest of the subcategories get no response.

Within the $\mathrm{C}_{7}$ (Figure 7) on knowledge or formal networks of enterprise development, understood as organizations composed by employers or public administrations which aims to facilitate connectivity and the exchange of information (Herrera, 2009), we can see that the answers of the entrepreneurs' DG and experts have different response rates, being higher percentages in the experts' DG than in that of the entrepreneurs', with the exception of AJE (Association of young entrepreneurs) on those who are higher in the entrepreneurs and StartupWeekend in which both groups (50\%) are equal.

Figure 8 referred to the $\mathrm{C} 8$ where response rates for difficulties and demands to start a business are collected, entrepreneurs' DG shows higher percentages in the subcategories of bureaucracy $(50 \%)$ and financing $(41.6 \%)$, while for the experts' DG are financing (87.5\%), lack of global vision of enterprise (62.5) and lack of free training in business management (37.5\%).

From the subcategories established in the $\mathrm{C} 9$ on the subjects of greater value for the development of entrepreneurial ability, the GD in which displayed replies is that of enterprise ow- 
Figura 8. Figura 8: Porcentajes de respuesta en C8 Dificultades y demandas para ser emprendedor

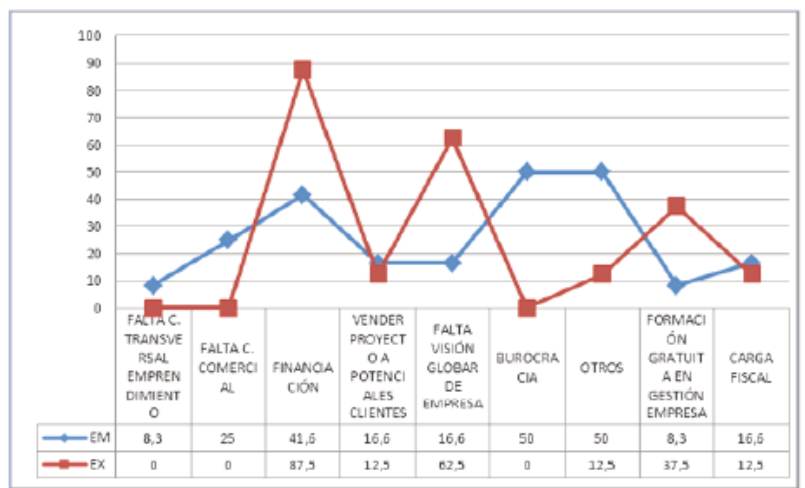

Fuente: Elaboración propia.

Figura 9. Porcentajes de respuesta en C9 Asignatura más valiosa para el emprendimiento

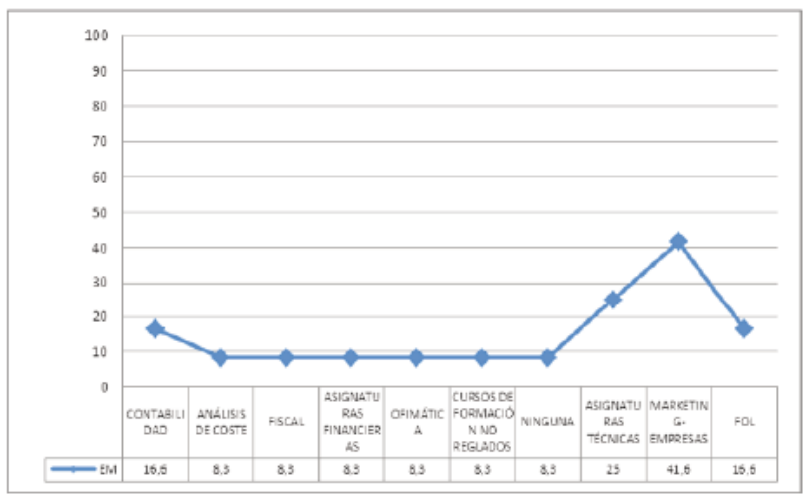

Fuente: Elaboración propia.

para el GD de expertos son la financiación (87,5\%), la falta de visión global de empresa $(62,5)$ y la falta de formación gratuita en gestión de empresa (37,5\%).

De las subcategorías establecidas en la C9 sobre las asignaturas de mayor valor para el desarrollo de la competencia emprendedora el GD en el que se muestran respuestas es en el de empresarios siendo las asignaturas que han recibido mayores tasas de respuesta las relacionadas con el marketing $(41,6 \%)$, asignaturas técnicas $(25 \%)$, contabilidad y FOL (16,6\%).

Los tramos educativos en los que los GD de Experto y Educadores muestran mayores tasas de respuesta para adquirir la competencia emprendedora son en los niveles de Infantil y Primaria (60\%) en Expertos y Secundaria y Bachiller (100\%) en Educadores.

Las tasas de respuesta referidas a la $\mathrm{C} 11$ sobre los organismos que asesoran en el emprendimiento se encuentran en el GD de educadores siendo las subcategorías que reciben mayores porcentajes: AJE, Universidad y Ayuntamiento (66,6\%).
Figure 8. Percentage of response for C8 Difficulties and demands to be an entrepreneur

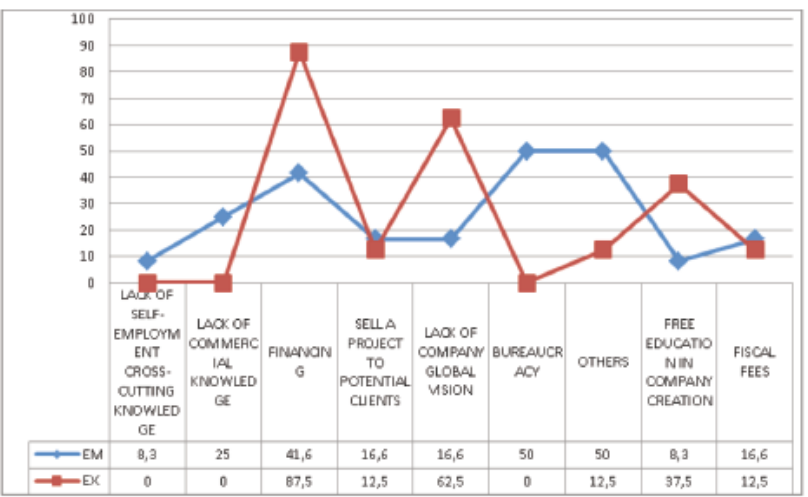

Source: Personal compilation.

Figure 9. Percentage of response for C9 Most valuable subject for entrepreneurship

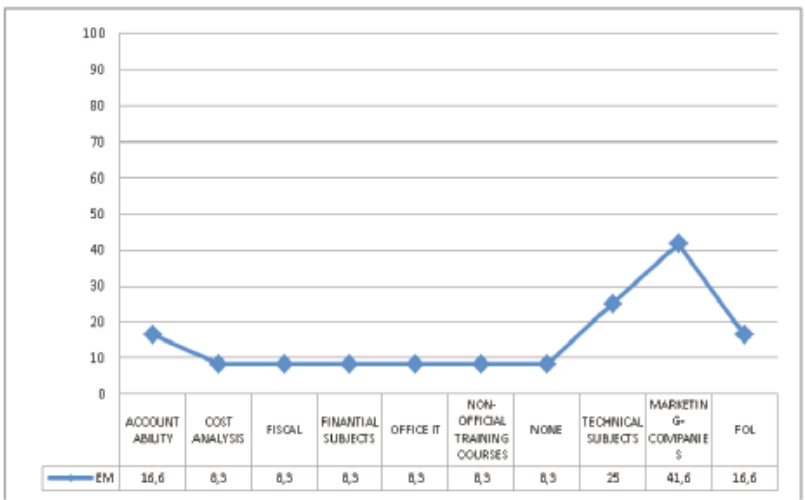

Source: Personal compilation.

ners being the subjects with higher response rates marketing-related (41.6\%), technical subjects (25\%), accounting and FOL (16.6\%).

Educational stages in which the DG's Expert and Educators show higher response rates to acquire entrepreneurial competition are at infant and primary levels (60\%) in Experts and middle school and high school (100\%) in Educators.

Response rates referred to the $\mathrm{C} 11$ on agencies that advise in the venture are the DG of educators being the subcategories of higher percentages: AJE, University and Town Hall (66.6\%).

Generally the percentage of response for $\mathrm{C}_{12}$ on the coordination between public and private agents regarding entrepreneurship, show negative aspects such as: there are not, it doubles, it is not enough or derivations occurs.

In this category there only are answers within the entrepreneurs DG, being new technologies the sector with the highest percentage of res- 
Figura 10. Porcentajes de repuesta en C10 Nivel educativo en los que adquirir las competencias emprendedoras

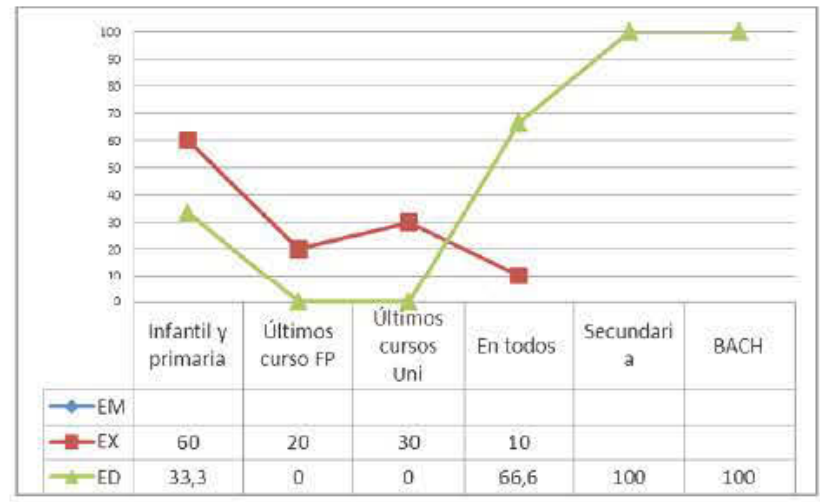

Fuente: Elaboración propia.

Figura 11. Porcentajes de repuesta en $\mathrm{C} 11$ Organismos que asesoran en el emprendimiento

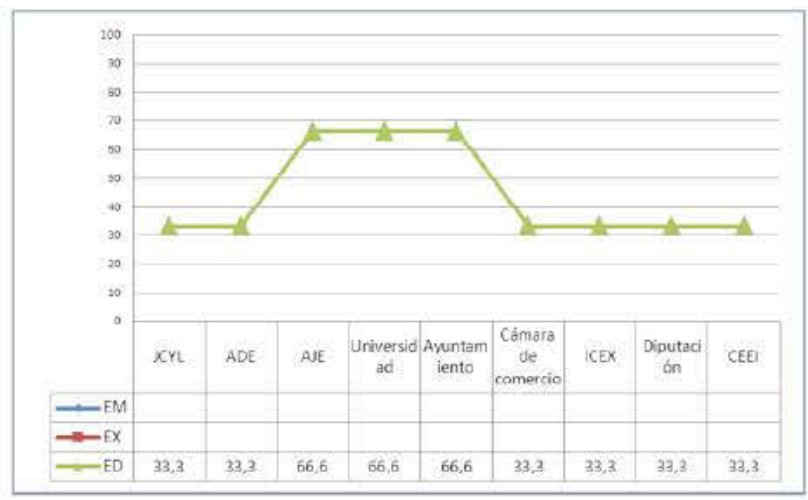

Fuente: Elaboración propia.

Figura 12. Porcentajes de respuesta en $\mathrm{C}_{12}$ sobre la coordinación existente entre los organismos públicos y privados con respecto al emprendimiento

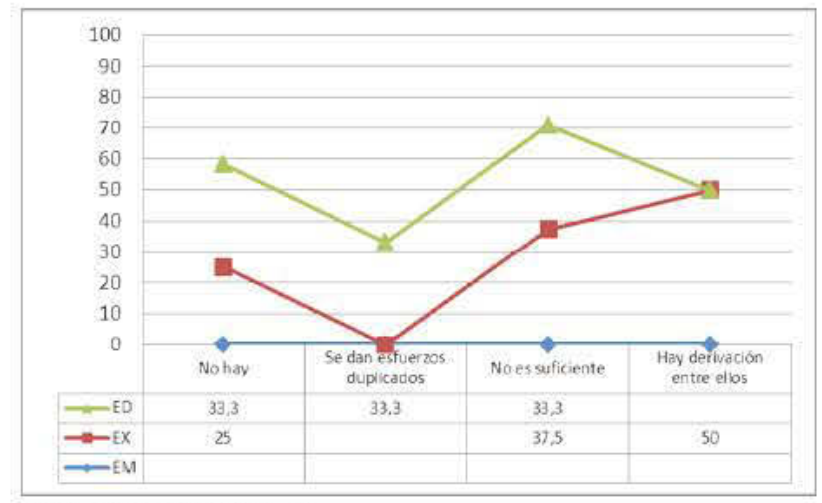

Fuente: Elaboración propia.

De forma general los porcentajes de respuesta en la $\mathrm{C}_{12}$ sobre la coordinación entre los organismos públicos y privados con respecto al emprendimiento muestran aspectos negativos tales como: no hay, se duplica, no es suficiente o se producen derivaciones.
Figure 10. Percentages of response for Cio Educational level in which to acquire entrepreneurial skills

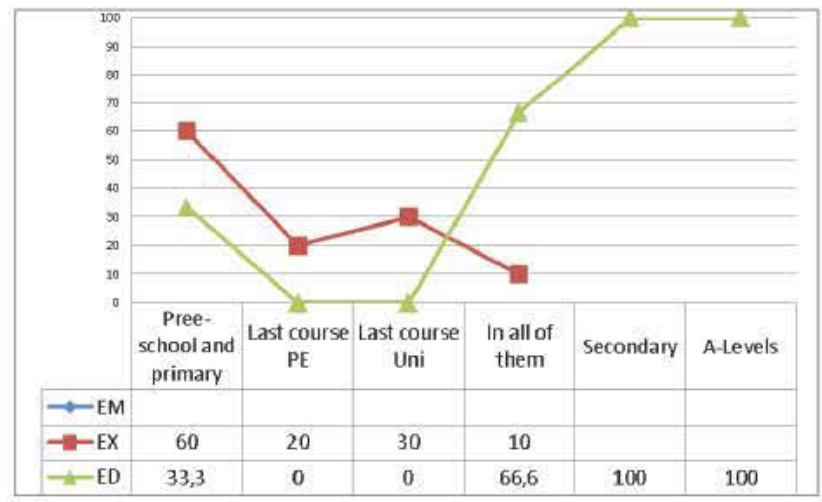

Source: Personal compilation.

Figure 11. Percentage of response for $\mathrm{C} n$ Agencies who advise on entrepr

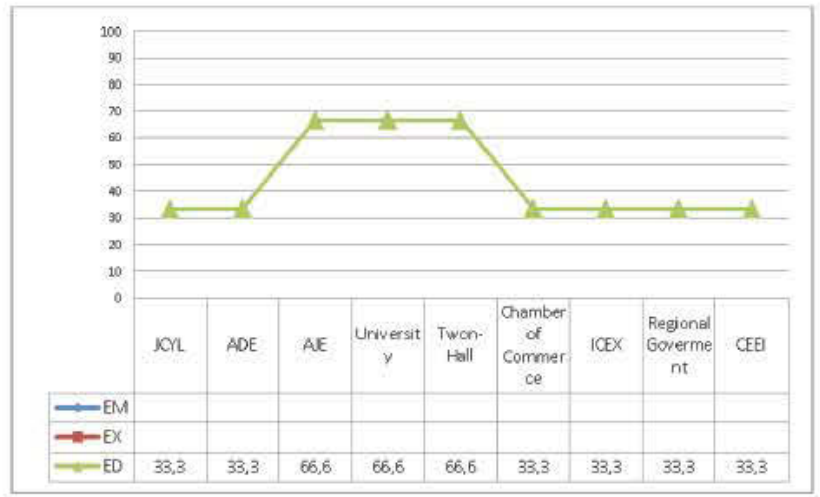

Source: Personal compilation.

Figure 12. Percentage of response for $\mathrm{C}_{12}$ on the existing coordination between the public and private agents regarding entrepreneurship

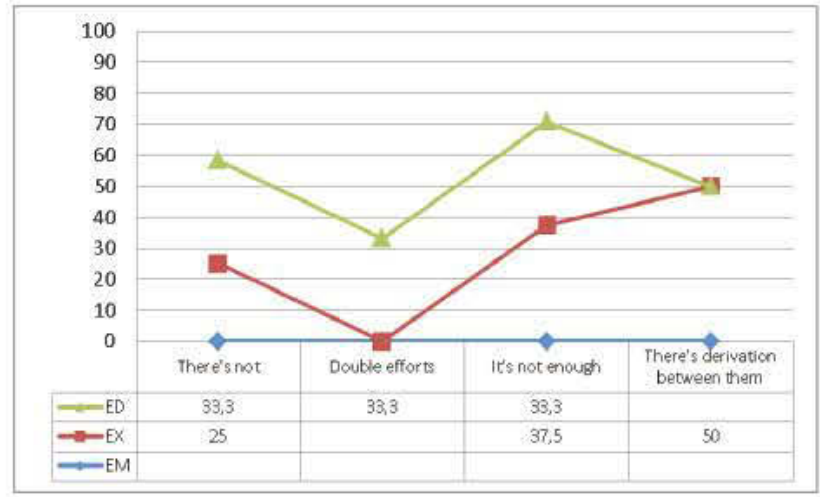

Source: Personal compilation.

ponse (66.6\%).

We then show the results obtained by the Discussion Group of entrepreneurs in the $\mathrm{C}_{14}$ category and $\mathrm{C}_{15}$ on skills developed at the beginning and during the development of entrepreneurial activities, being on this occasion this 
Figura 13. Porcentajes de respuesta en $\mathrm{C} 13$ sobre los sectores atractivos para el emprendimiento

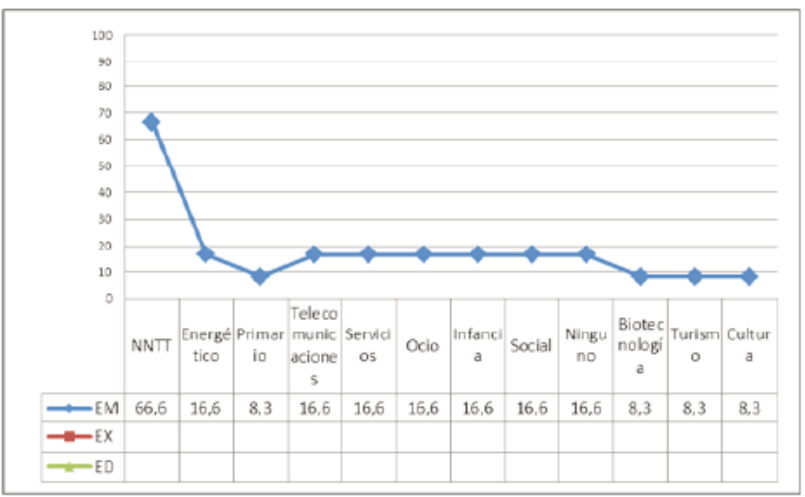

Fuente: Elaboración propia.

Figura 14. Porcentajes de respuesta en $C 14$ y $C 15$ Competencias desarrolladas al inicio y en el desarrollo de actividad emprendedora

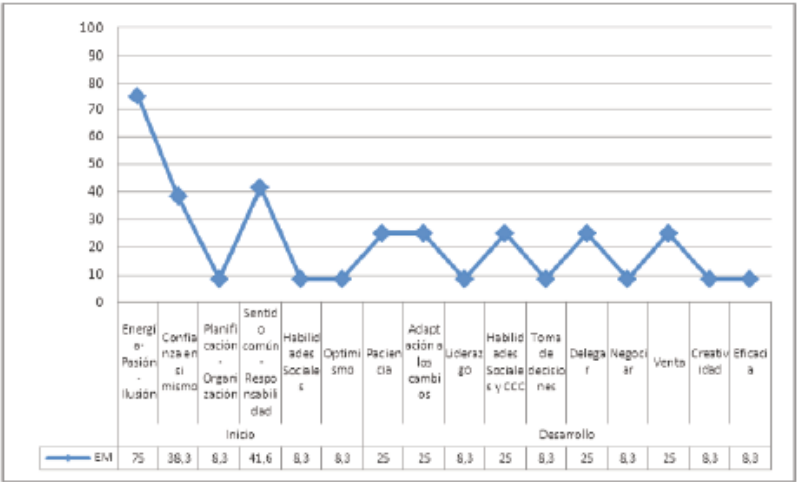

Fuente: Elaboración propia.

En esta categoría se producen sólo respuestas dentro del GD de empresarios, siendo el sector con mayor porcentaje de repuesta el referido a nuevas tecnologías (66,6\%).

Mostramos a continuación los resultados obtenidos por parte del Grupo de Discusión de emprendedores en la categoría $\mathrm{C} 14$ y C 15 sobre las competencias desarrolladas al inicio y durante el desarrollo de las actividades emprendedoras, siendo en esta ocasión este GD el único en el que se ha planteado este aspecto. De los resultados obtenidos ( Figura 7) resaltamos que en el inicio la competencia que más respuestas ha obtenido es la Energía- $\mathrm{Pa}$ sión- llusión con un $75 \%$, en segundo lugar el Sentido común y la responsabilidad con un $41,6 \%$ y la Confianza en sí mismo (38,3\%). Por otro lado, en el desarrollo de la actividad son varias las competencias que comparten el porcentaje de respuesta (25\%): Paciencia, Adaptación a los cambios, Habilidades sociales, Delegar y Venta.
Figure 13. Percentage of response for $\mathrm{C} 13$ on the attractive sectors for entrepreneurship

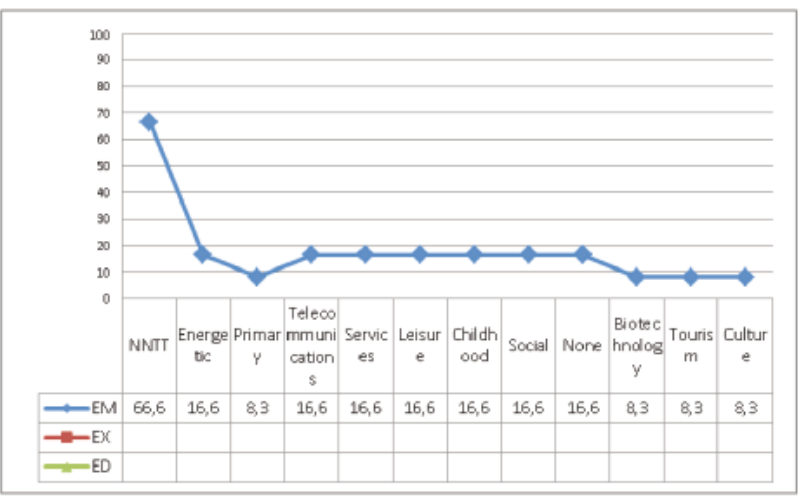

Source: Personal compilation.

Figure 14. Percentage of response for $\mathrm{C} 14$ and $\mathrm{C}$ 15 Competencies developed at the beginning and the development of entrepreneurial activity

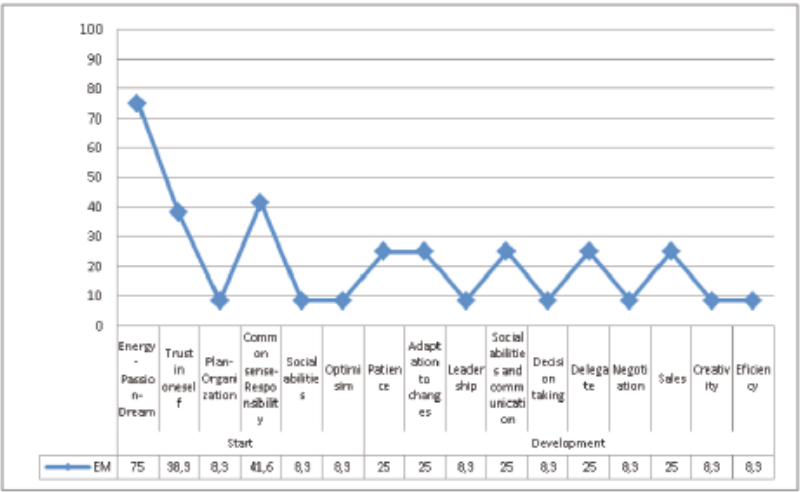

Source: Personal compilation.

DG the only one in which this aspect has been raised. From the obtained results (Figure 7), we highlight that in the beginning the ability with more answers is the Power - Passion - Dream with a 75\%, second Common sense and responsibility with a $41.6 \%$ and the Self-confidence (38.3\%). On the other hand, in the development of the activity there are several abilities with 25\%: Patience, adapting to changes, social skills, delegating and sale. 


\subsection{Resultados globales}

Tras el análisis descriptivo de los resultados obtenidos en las categorías y subcategorías establecidas se observa que tanto los emprendedores como los educadores ven como aspecto clave para el emprendimiento la resolución de problemas desde un punto de vista diferente, así como un proyecto de vida, en consonancia con la definición aportada por Pérez González (2013).

En las motivaciones que llevan a emprender los empresarios ven como principal motivación realizar el trabajo deseado mientras que los expertos y educadores como necesidad laboral por desempleo.

Dentro de los organismos que proporcionan ayudas económicas al emprendimiento el grupo de emprendedores tiene un menor conocimiento de las instituciones que las proporcionan, con respecto a los educadores y expertos que obtienen mayores tasas de respuesta. Por otro lado, es destacable que los emprendedores apuntan a la familia como fuente de financiación mientras que los educadores y expertos no la contemplan.

Como conocimientos necesarios para emprender se muestran la gestión de empresas, conocimientos técnicos y nuevas tecnologías, así como los conocimientos transversales sobre autoempleo. Estos resultados están en la línea de los trabajos de Hornaday (1971), Chandler y Jansen (1992) y Rathna y Vijaya (2009).

En la categoría sobre la formación a incorporar en la ESO y FP los grupos de expertos y educadores muestran porcentajes similares mientras que los emprendedores se distancian con puntuaciones menores. En concreto, expertos y educadores orientadores incorporarían conocimientos transversales de autoempleo y los emprendedores incorporarían conocimientos en gestión de empresas.

Las competencias y habilidades útiles muestran referencias similares entre los $G D$, atribuyéndose a las habilidades sociales, seguido de perseverancia y capacidad de trabajo, de sentido común, de imaginación y creatividad, de liderazgo y de iniciativa. Estos resultados se relacionan con los estudios de Hornay (1971), García Cabrera et al. (2014), Man et al. (2002) y Man et al. (2008).

En el conocimiento de redes de emprendimiento por parte del grupo de educadores no se obtienen respuestas, aunque sí muestran respuesta por parte de los organismos que asesoran para el emprendimiento. Por otro lado, el grupo de expertos y emprende-

\subsection{Global results}

After the descriptive analysis obtained for the established categories and subcategories, it is detected that both entrepreneurs and educators see problem solving as a key aspect for entrepreneurship from a different point of view, according to Pérez González (2013).

Among the motivations that lead EMPRESARIOS to start a business the main one is to perform a desired job while aspect highlight the necessity for a job for unemployed people.

Within the administrations that provide economic aids for starting a business the entrepreneur's group knows them better, in regard to educators and experts obtaining higher response rates. Moreover, entrepreneurs pointed to family as financial source while educators and experts don't consider it.

Among the necessary capacities to start a business are company's management, technical knowledge and new technologies, as well as cross-cutting self-employment knowledge. Those results are similar to those of Hornaday (1971), Chandler and Jansen (1992) and Ratna and Vijaya (2009).

In the category of formation to add to GCSE or $\mathrm{PE}$, the experts and educators show similar registers while entrepreneurs have lower results. Precisely, experts and career advisers will add cross-cutting self-employment knowledge and the entrepreneurs company management' knowledge.

There are similar rates among the DG regarding the useful competences and abilities; social abilities, common sense, imagination and creativity, leadership and initiative. Those results are related to studies of Hornay (1971), García Cabrera et al. (2014), Man et al. (2002) and Man et al. (2008).

There are no responses for network's knowledge on the educators group, although there are some on the administrations advising the entrepreneurs. On the other hand, the experts and entrepreneurs speak of the same networks but in different rates.

If we consider the difficulties for starting a job, we see those referred to training on a different classification of 4 categories: transversal, commercial, management and marketing knowledge, being the most valued subjects: marketing, accountability, tech- 
Figura 15. Categorías inductivas establecidas tras la realización de los Grupos de Discusión y su correspondencia con las establecidas de forma deductiva

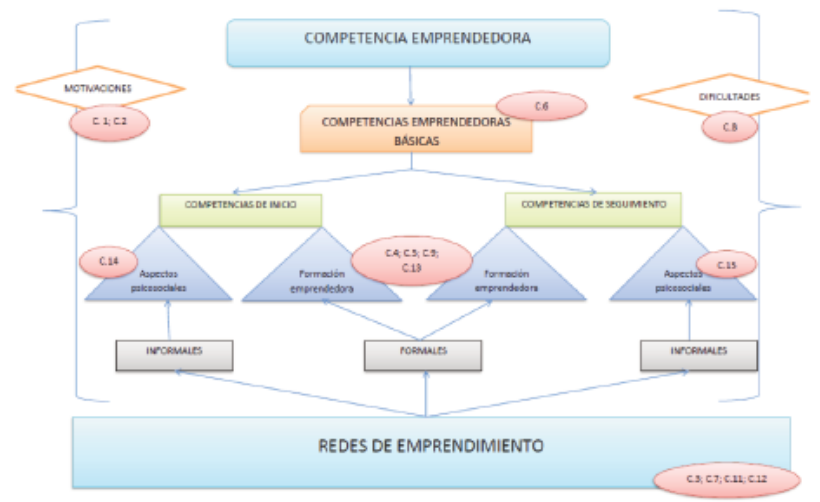

Fuente: Elaboración propia.

dores conocen las mismas redes aunque con tasas de respuesta diferentes.

Si consideramos las dificultades que se encuentran para emprender observamos como las referidas a formación se ven reflejadas de diferente forma en cuatro subcategorías: conocimientos transversales, comerciales, de gestión y marketíng, siendo coincidentes con las asignaturas más valiosas: marketing, contabilidad, técnicas y FOL. Así los tramos educativos en los que incorporar los conocimientos sobre emprendimiento se centran en las etapas correspondientes a la educación secundaria.

Los emprendedores muestran como al inicio de su actividad emprendedora contaban especialmente con energía, pasión e ilusión, sentido común y responsabilidad, valorándolas como aspectos clave para iniciar la actividad emprendedora. En cuanto a las competencias que han ido desarrollando a lo largo de su actividad emprendedora se encuentran principalmente la paciencia, adaptación a los cambios, habilidades sociales y de comunicación, capacidad para delegar y habilidades para la venta.

Retomando el objetivo específico de este artículo centrado en determinar la formación y competencias necesarias para crear empresa así como la motivación y las dificultades que existen para ello y basándonos en los resultados aportados en el análisis descriptivo de las contribuciones realizadas por los grupos de discusión hemos realizado una reorganización inductiva de las categorías previas establecidas de forma deductiva.

Tal y como se observa en la figura 15 la competencia emprendedora está formada de competencias bá-
Figure 15. Inductive categories established after the creation for the Discussion Groups and its correspondence with those deductively established

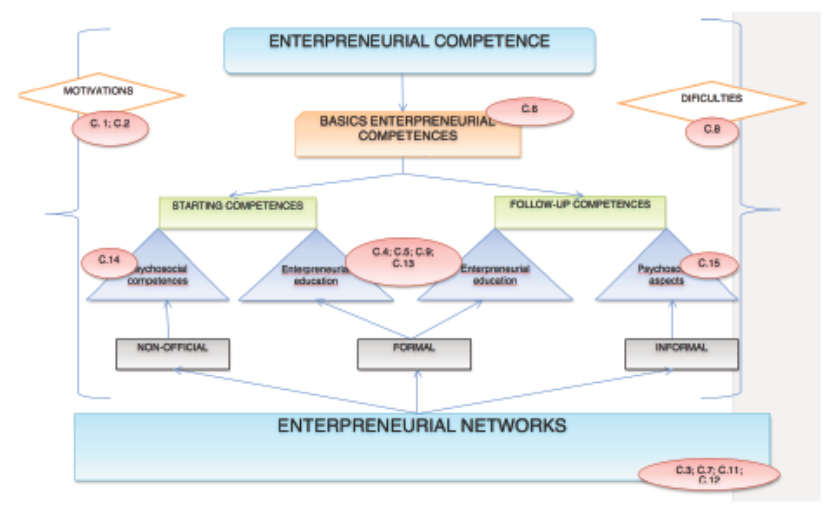

Source: Personal compilation.

nical and FOL. Thus, this entrepreneurship knowledge is inserted in secondary education.

Entrepreneurs explain that at the beginning of their activity they were full of energy, passion and dream, common sense and responsibility, valuing those as key for starting a business. Regarding the competences developed while stating a business they point out patience, adaptation to changes, social and communication competences, capacity to delegate and sales.

If $w$ ego back to the main objective of this paper to determine the necessary training and competences to start a company as well as the motivation and difficulties existing, and base don the results of the descriptive analysis by discussion groups, we have categorized the previous categories deductively.

As observed in the figure 15 , the entrepreneurship competence is based on basic entrepreneurship competences (C6: Useful competences and abilities) CONCRETAN depending on the stage of the entrepreneurship process we are, separating starting and follow-up competences. The starting competences are made of the psychosocial aspects of the entrepreneur's profile (C14: Starting competences) and training entrepreneurship' competences ( $\mathrm{C}_{4}$ : Necessary competences to start a business; $\mathrm{C}_{5}$; Training to incorporate GCSE and PE; C9: most valued subjects; and C13: More attractive sectors). Among the follow-up competences we find training entrepreneurship competences, matching the starting ones, and the psychosocial aspects of the entre-

[ 242 ] Ma ISABEL LUIS RICO, CARMEN PALMERO CÁMARA Y Ma CAMINO ESCOLAR LLAMAZARES

SIPS - PEDAGOGIA SOCIAL. REVISTA INTERUNIVERSITARIA [1139-1723 (2015) 25, 221-250] TERCERA ÉPOCA 
sicas emprendedoras (C 6: Competencias y habilidades útiles) que se concretan según el momento del proceso emprendedor que nos encontremos, distinguiendo entre competencias de inicio y competencias de seguimiento. Las competencias de inicio están conformadas por aspectos psicosociales del perfil del emprendedor (C 14: Competencias de inicio) y de competencias de formación emprendedora ( $\mathrm{C}_{4}$ : Formación necesitada para crear empresa; $C_{5}$ : Formación a incorporar a ESO y FP; C9: asignaturas más valiosas; $y$ C13: Sectores más atractivos). Dentro de las competencias de seguimiento encontramos las competencias de formación emprendedora, coincidentes con las de inicio, y los aspectos psicosociales del perfil del emprendedor ( $\mathrm{C}_{15}$ : Competencias desarrolladas por los emprendedores). Tanto las motivaciones para ser emprendedor ( $\mathrm{C}_{1}$ : Definición de emprendimiento y $\mathrm{C}_{2}$ : Motivos para emprender) como las dificultades (C8: Dificultades encontradas para emprender) influyen en la competencia emprendedora.

Las redes de emprendimiento atañen a la configuración tanto de las competencias de inicio como de seguimiento ( $\mathrm{C} 3$ : ayudas económicas; $\mathrm{C}$ 7: conoce o ha desarrollado redes de emprendimiento; $\mathrm{C} 11$ : organismos que asesoran; y $C_{12}$ : coordinación entre organismos, aunque difieren entre redes informales $y$ formales de emprendimiento según se refieran a los aspectos psicosociales o de formación emprendedora respectivamente.

\section{Conclusiones}

El presente trabajo, consciente de la complejidad de la interacción entre educación y emprendimiento y de las posibles vías metodológicas de estudio, ha optado por el análisis de los grupos de discusión, buscando con ello una mayor comprensión del fenómeno y vías complementarias para verificar el papel decisivo de la educación en las tasas de emprendimiento.

El desarrollo de este estudio ha sido una excelente oportunidad para contribuir a la literatura existente sobre diseño y gestión de Grupos de Discusión como metodología cualitativa de análisis de una realidad. La experiencia en la realización de los GD ha sido positiva, ya que se ha conseguido establecer y pautar un procedimiento de actuación para la eficiente conducción de este tipo de metodología y que ha proporcionado resultados constituidos por un total de 100 subcate- preneur's profile ( $\mathrm{C}_{15}$ : Competences developed for entrepreneurs). Both motivations to be entrepreneur ( $\mathrm{C}_{1}$ : Definition of starting a business and C2: Motivation to start a business) as well as difficulties to start a business (C8: Difficulties for starting a business) influence its entrepreneurial competence.

The entrepreneurial network refers to the configuration both of starting the follow-up competences (C3: economic aid; $C_{7}$ : know or have develop entrepreneurial networks; $\mathrm{C}_{11}$ : administrations that they advise; and C12: coordination between administrations, even if they differ from the formal and informal networks of entrepreneurship depending if it refers to the psychosocial or training aspects respectively.

\section{Conclusions}

This paper, being of the interaction between education and entrepreneurship and the possible methodological aspects of this research, has chosen the discussion group analysis in order to get a better comprehension and its complementary aspects to verify the essential role of education in entrepreneurship rates.

This research has been an excellent opportunity to contribute to the existing literature on Discussion Group's design and management as a qualitative methodology for analysing reality. The experience in the development of DG has been positive, because an effective action procedure has been established and limited for the efficient lead of this kind of methodology. It has lead to results of over 100 subcategories divided into five di- 
gorías divididas en cinco dimensiones: conocimientos, habilidades, actitudes, valores y comportamiento deseados.

Al mismo tiempo, se ha podido comprobar como no todas las competencias y habilidades útiles para el emprendimiento adquieren el mismo grado de importancia en función de la extracción de los participantes en el grupo de discusión, lo que abre nuevas vías para el estudio inferencial de estas valoraciones. Adicionalmente, se demuestra la percepción de una notable distancia entre lo que el emprendedor necesita en sus primeros pasos y lo que la sociedad, en forma de educadores y servicios especializados, le ofrece. Se observa en este sentido la necesidad de revisar el curriculum de secundaria

En cuanto al análisis de las necesidades educativas, se observa la discrepancia existente entre lo que valoran como necesario los emprendedores y los expertos. Como hemos señalado en los resultados, los emprendedores (coinciden con los educadores) reclaman formación sobre gestión de empresas, con conocimientos como marketing, contabilidad o economía. Mientras que los expertos creen necesaria como formación para emprender conocimientos transversales sobre autoempleo (planes de empresa, negociación, desarrollo de proyectos.....). Ciertamente, en lo que sí coinciden los tres grupos es en la necesidad de conocimientos técnicos que por otra parte están relacionados con el perfil profesional del emprendedor y que por tanto ya se están aportando a través de la educación formal. Esta tendencia se vuelve a observar cuando señalan el tipo de formación que incorporarían a la ESO y a la formación profesional. Donde expertos y educadores incorporarían conocimientos transversales al autoempleo mientras que los emprendedores vuelven a señalar conocimientos sobre gestión empresarial. Por lo tanto, la discrepancia sobre necesidades educativas y expectativas entre emprendedores y los servicios especializados en emprendimiento y los educadores, es evidente. En cuanto a las competencias útiles para el emprendimiento valoradas por los tres grupos de discusión, éstas estarían en consonancia con las planteadas por autores como García Cabeza et al. (2014). Destacando por ejemplo, las habilidades de relación o interpersonales, de compromiso y fortaleza personal y de responsabilidad.

Por último, se identifica un conjunto de relaciones que pueden favorecer la creación de empresas y cuyo mensions: knowledge, abilities, attitudes, values and desired behaviours.

At the same time, it was detected that not all the useful competences an abilities for entrepreneurship are as important regarding the extraction of participants in the discussion groups, so new paths for the inferential study of this assessments are opened. Additionally, a huge distance is perceived between what an entrepreneur needs at the beginning and what society offers (by means of educators and specialized services). Thus secondary education' program should be revised.

Regarding the educational necessities analysed, there is no agreement among what is valued for entrepreneurs and educators. As underlined before, entrepreneurs (as well as educators) claim for an education on business management, such as marketing, accountability or economics. While experts find essential to have cross-cutting selfemployment knowledge (company PLAN, negotiation, project development...). CIERTAMENTE, the three groups agree on the need for technical knowledge related to the professional profile of the entrepreneur and acquired throughout formal education. This trend appears again when pointing out the education that they will add to GCSE and professional education. Where experts will add self-employment cross-cutting knowledge while entrepreneurs will add business management instead. So, this DISCREPANCIA on educational needs among educators and expectations among entrepreneurs and the entrepreneurial specialized services is visible. Regarding the useful competences for entrepreneurship assessed by the three discussion groups, will agree to those of García Cabeza et al. (2014). Relationship or interpersonal abilities, of compromise and personal strength and responsibility, are underlined.

Finally, a group of relations that could help the creation of business and that could be useful for educators and to plan the formation are identified. Thus, the motivation to start a new business for an entrepreneur is much more related to an intrinsic other than extrinsic motivation. Facing what society believes. They are often financed by their families, and sometimes by the most com- 
conocimiento puede resultar útil para los educadores y la adecuada planificación de sus disciplinas formativas. Así, la motivación que a un emprendedor le lleva a crear su propio negocio está más relacionada con una motivación intrínseca que extrínseca. Al contrario de lo que la sociedad creemos. En cuanto a la financiación de la que se sirven, en muchas ocasiones proviene de su propia red familiar. Si bien es cierto que también recurren a la financiación pública más habitual y a la que se refieren también tanto los expertos como los educadores.

Todo ello permite identificar las distintas competencias que los actores económicos y educativos relacionan con el emprendimiento. $\mathrm{Y}$, de forma paralela, se obtiene la percepción que estos mismos actores tienen de los resultados de los sistemas educativos en competencias emprendedoras, apuntándose las vías por las que se debe proceder a su reforma curricular, objetivo ineludible en aquellos países, como España, que desean incrementar los niveles naciones de emprendimiento.

Por lo tanto, aunque exista un gran debate en torno a las interacciones entre educación y emprendimiento, nuestro estudio permite afirmar que el curriculum es el instrumento idóneo para la adquisición de competencias relacionadas con la creación de empresas, y los resultados obtenidos del grupo de discusión reclaman una revisión del curriculum de la educación secundaria obligatoria y la enseñanza profesional que debe configurarse como la institución en la que se aprende a compartir, dialogar y adquirir conocimientos técnicos -especialmente se subrayan los que guardan relación con idiomas, nuevas tecnologías y legislación-y habilidades sociales de comunicación, liderazgo, adaptación al cambio, responsabilidad y trabajo en equipo.

Sin eludir las funciones que las sociedades modernas atribuyen a los sistemas educativos en la construcción de una sociedad más justa y cohesionada, se debe profundizar en el diseño curricular y organizativo para que la educación secundaria y profesional respondan también a la demanda social y económica, aparecida con notable énfasis a lo largo de esta última década, de incrementar la creación de empresas, asumiendo entre sus objetivos que los jóvenes que alcanzan estas cotas educativas hayan adquirido las competencias asociadas a la tarea de poner en marcha su propia actividad empresarial y el autoempleo que requiere la sociedad del siglo XXI. mon public administrations, as experts and educators referred.

All that enables to identify different competences related to entrepreneurship by economic and social actors. At the same time, the perception that those actors have of the educative systems on entrepreneurship's results is obtained. In that sense, it is point out how to act in the curricula reformation, main objective for countries that as Spain wish to increase the national levels of entrepreneurship.

As a consequence, even if there is a huge debate among the interrelation between education and entrepreneurship, our research states that the curricula is the best toll for the acquisition of competences for starting a business. The results obtained in the discussion group claim for a revision of the secondary education and professional education program that should a period for sharing, debate and acquire technical knowledge (mainly languages, new technologies and legislation) and social abilities such as communication, leadership, adaptation to change, responsibility and team work.

Without forgetting the role that modern societies give to educational systems in the building of a more cohesive and JUSTA society, we should work on the education program and organization so secondary education and professional education meet the social and economic needs, as seen in the last decade; the necessity of increase the creation of companies, assuming that the young people with this education have the required competences to start their own business as the society of the $21^{\text {st }}$ Century requires. 


\section{REFERENCIAS BIBLIOGRÁFICAS/ BIBLIOGRAPHIC REFERENCES}

Agarwal, R., Audretsch, D.B., \& Sarkar MB. (2007). The process of creative construction: Knowledge spillovers, entrepreneurship, and economic growth. Strategic Entrepreneurship Journal 7(3-4), 263-286.

Ahmad, N. H., Halim, H. A., \& Zainal, S. R. M. (2010). Is entrepreneurial competency the silver bullet for SME success in a developing nation? Interdisciplinary Journal of Contemporary Research in Business, 2(1), 217-236.

Ahmad, N. H., Wilson, C., \& Kummereow, L. (2011). A cross-cultural insight into the competency-mix of SME entrepreneurs in Australia and Malaysia. Journal of Business and Management Science, 4(1), 33-50.

Attewell, P. (2009). ¿Qué es una competencia? Pedagogia Social. Revista Interuniversitaria, 16, 21-43. doi:10.7179/PSRI.

Bas Peña, E. (2007). El Prácticum en la Titulación de Pedagogia: discurso y practica profesional. Pedagogía Social. Revista Interuniversitaria, 14, 139-153. doi:10.71797/PSRI.

Baumol, W.J. (2004). The free-market innovation machine: Analyzing the growth miracle of capitalism. Princeton University Press: Princeton.

Baumol, WJ., \& Strom, R.J. (2007). Entrepreneurship and economic growth. Strategic Entrepreneurship Journal 7(3-4), 233-237.

Binks, M., Starkey, K., \& Mahon, C.L. (2006). Entrepreneurship education and business school. Technology Analysis and Strategic Management, 18(1), 1-18

Cano Garcia, M. E. (2008). La evaluación por competencias en la educación superior. Profesorado. Revista de Curriculum y Formación de Profesorado, 12(3), 1-16.

Chandler, G. N. \& Jansen, E. (1992). The founder's self-assessed competence and venture performance. Journal of Business Venturing, 7 (3), 223-236.

Davidsson, P. (2004) Researching entrepreneurship International Studies in Entrepreneurship. Boston: Springer Science Inc.

Davidsson, P. \& Honig, B. (2003). The role of social and human capital among nascent entrepreneurs. Journal of Business Venturing. 18(3): 301-331.

Delmar, F. \& Davidsson, P. (2000). Where do they como from? Prevalence and characteristics of nascent entrepreneurs, Entrepreneurship \& Regional Development, 12, 1-23.

Escudero Muñoz, J. M. (2009). Las competencias profesionales y la formación universitaria : posibilidades y riesgos. Pedagogia Social. Revista Interuniversitaria, 16, 65-82. doi:10.7179/PSRI.

Fourie, L. (2008). Establishing a culture of intrapreneurship as a contributor to sustainable economic growth. Journal of Business Venturing, 7(3), 223-236.

Freytag, A. \& Thurik, A.R. (2007) Entrepreneurship and its determinants in a cross country setting, Journal of Evolutionary Economics, 17(2), 117-131.

García Cabrera, A. M., Déniz Déniz, M. C., Garcia Soto, M. G., Martin Santana, J. D., Suárez Ortega, S. M., \& Cabrera Suarez, M. K. (2014). ¿Los títulos de administración de empresas adaptados al EEES en España forman directivos emprendedores? Bordón. Revista de Pedagogía, 66(2), 75-92. doi:10.13042/Bordon.2014.66205.

Gonczi, A. (2003). Teaching and learning of the key competencies. En Rychen, D.S., Salganik, L. H., \& McLaughlin, M. E. (Eds.) 97-99. Contributions to the Second DeSeCo (Definition and Selection of Key Competencies) Symposium. Neuchâtel: Swiss Federal StatisticalOffice.

Grilo, I. \& Thurik, R. (2005) Latent and actual entrepreneurship in Europe and the US: some recent developments, International Entrepreneurship and Management Journal, 1(1), 441-459.

Herrera Echeverri, H. (2009): Investigación sobre redes sociales y emprendimiento. Revisión de la literatura y agenda futura. Innovar Journal, vol. 19 (33), 19- 33.

Hornaday, J. A. (1971) Research about living entrepreneurs. In G. A. Kent, D. L. Sexton y K. H. Vespes (ed.), Encyclopedia of Entrepreneurship, 20-34. Englewood Gliffs, NJ: Prentice Hall.

[ 246 ] Ma ISABEL LUIS RICO, CARMEN PALMERO CÁMARA Y Ma CAMINO ESCOLAR LLAMAZARES

SIPS - PEDAGOGIA SOCIAL. REVISTA INTERUNIVERSITARIA [1139-1723 (2015) 25, 221-250] TERCERA ÉPOCA 
Jiménez, A, Palmero, C \& Alonso, P. (2005). Educación Superior y empleo. Escenarios, desafíos formativos y compromisos de sus actores. Análisis desde el caso español. Revista de la Educación Superior, 133, 53-64.

Jiménez Palmero, A, Palmero Cámara, C. \& Jiménez Eguizábal, A. (2012). El impacto de la educación secundaria y superior en la creación de empresas en la Unión Europea, Revista Española de Pedagogía, 252, 201219.

León, O. G. \& Montero, I. (2012). Métodos de Investigación en Psicologia y Educación (p. 454). Madrid: Mc Graw Hill / Interamericana de España S.A.U.

Luis, I., De la Torre, T., Gañán, A., Palmero, C. \& Jiménez, A. (2013). Formación universitaria para mayores: innovación curricular y competencias emprendedoras. International Journal of Developmental and Educational Psychology, 2(l), 175-186.

Man, T.W.Y. (2001). Entrepreneurial competences and the performance of small and medium enterprise in the Hong Kong services sector (Tesis doctoral en el Departamento de Gestión de la Universidad Politécnica de Hong Kong). Base de Datos ProQuest Information and Learning, Universidades Politécnica de Hong Kong, Hong Kong.

Man, T. W.Y., Lau, T. \& Chan, K.F. (2002). The competitiveness of small and medium enterpreises: a conceptualizaction with focus on entrepreneurial competences. Journal of Business Venturing, 17(2), 123-142.

Man, T. W.Y., Lau, T. \& Snape, E. (2008). Entrepreneurial competencies and the performance of small and medium enterprises: An investigation through a framework of competitiveness. Journal of Small Business and Entrepreneurship, 27 (3), 257-276.

Martinez-Mediano, C., Lord, S. M. \& Rioperez Losada, N. (2013). Programa de Desarrollo de Competencias para el Aprendizaje a lo Largo de la Vida para Estudiantes de Educación Superior. Pedagogia Social. Revista Interuniversitaria, 22, 137-151. doi:10.7179/PSRI.

McClelland, D.C. (1975). Power: the inner experience. New York, Irvington.

Moya M. (2008). Worldwide Business startups. Disponible en http:// www.moyak.com/researcher/resume/ papers/business_startups.html.

North, D.C. (1990). Institutions, institutional change and economic performance. Cambridge: University Press.

Pérez Gonzalez, M. J. (2013). Emprendimiento, iniciativa y creatividad. In Cómo ser competente. Competencias profesionales demandadas en el mercado laboral (pp. 108-112). Salamanca: Servicio de Inserción Profesional Practicas y Empleo.

Pérez Serrano, G. (2000): Modelos de investigación cualitativa en educación social y animación sociocultural. Revista de Psicodidáctica, 14, 5-40.

Ramos Sánchez, J. L. (2011). Investigación cualitativa. In S. Cubo Delgado, B. Martín Marín, \& J. L. Ramos Sánchez (Eds.), Métodos de investigación y análisis de datos en ciencias sociales y de la salud (pp. 411-456). Madrid: Ediciones Pirámide.

Rathna, K. G. \& Vijaya, T. G. (2009). Competencies of entrepreneurs and intrapreneurs: A comparative study. South Asian Journal of Management, 16 (2), 28-46.

Perrenoud, P. (2009). Enfoque por competencias, ¿̇una respuesta al fracaso escolar? Pedagogia Social. Revista Interuniversitaria, 16, 45-64. doi:10.7179/PSRI.

Quecedo, R. \& Castaño, C.: Introducción a la metodología de investigación cualitativa. Revista de Psicodidáctiva, 14, 5-10.

Reyero, D. (2009). El peso del Estado en la educación. Una aproximación crítica desde la economía liberal. Revista Española de Pedagogía, 244, 409-425.

Sáez, F. (Coord.) (2000). Formación y empleo. Fundación Argentaria. Visor: Madrid.

Uhlaner, L. \& Thurik, R. (2007). Postmaterialism influencing total entrepreneurial activity across nations, Journal of Evolutionary Economics, 17(2), 161-185.

Valdemoros, M.A., Ponce de León, A. \& Sanz, E. (2011): Fundamentos en el manejo del NVIVO como herramienta al servicio de estudios cualitativos. Contextos educativos 14, 11-29. 
Valliere, D. \& Peterson, R. (2009). Entrepreneurship and economic growth: Evidence from emerging and developed countries. Entrepreneurship and Regional Development, 21 (5), 480-559.

Wennekers, A.R.M. \& Thurik, A.R. (1999). Linking entrepreneurship and economic growth. Small Business Economics, 13(1), 27-55.

Zacharakis, A.L., Bygrave, W.D. \& Shepherd, D.A. (2000). Global entrepreneurship monitor: National entrepreneurship assessment: United States of America. Kansas City: Kauffman Center for Entrepreneurial Leadership.

Apéndice 1

Esquema del grupo de discusión. Emprendedores

1. Breve presentación del Proyecto de Investigación por parte de su directora, la profesora Dra. Carmen Palmero.

2. Presentación personal de cada participante del Grupo de Discusión. Durante 2 minutos se expondrá: Nombre,

Empresa, Actividad empresarial, Ámbito de actuación (local, regional, nacional, internacional)

3. Bloque de Emprendimiento. Cómo definirías el emprendimiento desde tu propia experiencia

4. Bloque de Contextualización

a. Qué motivos te impulsaron a ser emprendedor y en qué momento.

b. ¿Tuviste apoyo familiar-social para montar tu empresa? ¿Fue importante tenerlo?

c. Qué ayudas económicas tuviste para la creación de tu empresa. Qué organismos oficiales te las proporcionaron.

d. Qué dificultades, en general, tuviste para conseguir tu objetivo de ser emprendedor.

e. En la actualidad, qué sectores pueden ser más atractivos para crear una empresa.

5. Bloque de Formación

a. Qué formación concreta necesitaste para crear tu negocio.

b. Qué asignaturas cursadas a lo largo de tu formación consideras que te ayudaron más para la creación de tu empresa.

Qué competencias/habilidades consideras útiles para gestionar con éxito el emprendimiento.

d. Cuáles tenias al inicio de la creación de tu empresa y cuáles has ido adquiriendo posteriormente. ¿Consideras importante entrenar en este tipo de competencias a los futuros emprendedores?

e. Qué formación incorporarias en el sistema educativo (ESO y FP) para fomentar el emprendimiento.

6. Redes de Emprendimiento

7. Conclusiones

¿Conoces las Redes de Emprendimiento?: Su propósito y actividades para los emprendedores. ¿Eres niembro de alguna?, en su caso, mencionarla.

Esquema del grupo de discusión. Expertos: agentes económico y social

1. Breve presentación del Proyecto de Investigación por parte de su directora, la profesora Dra. Carmen Palmero.

2. Presentación profesional de cada participante del Grupo de Discusión.

3. Bloque de preguntas

a. Qué motivos impulsan actualmente a ser emprendedor.

b. Qué ayudas económicas existen para la creación de empresas.

c. ¿Existe coordinación entre los organismos que asesoran en la creación de empresas?

d. Qué necesidades, en general, demandan los emprendedores actuales.

e. Qué formación concreta es importante para crear una empresa. Cuál se debería incorporar en el sistema educativo (ESO y FP) para fomentar el emprendimiento.

f. De las competencias/habilidades que se consideran útiles para gestionar con éxito el emprendimiento, en qué nivel educativo se deben adquirir.

4. Conclusiones actividades que realizan.

Esquema del grupo de discusión. Educadores y orientadores

1. Breve presentación del Proyecto de Investigación por parte de su directora, la profesora Dra. Carmen Palmero

2. Presentación personal de cada participante del Grupo de Discusión. Durante 2 minutos se expondrá: Nombre.

Centro Docente, Ámbito de actuación (local, regional, nacional, internacional)

3. Bloque de Emprendimiento. Cómo definirias el emprendimiento

4. Bloque de Contextualización

a) ¿Qué motivos impulsan actualmente a ser emprendedor?

b) ¿Qué formación concreta es importante para crear una empresa?

c) ¿En qué nivel educativo se debe adquirir?

d) En el caso de que varíe ¿En qué nivel educativo se están impartiendo en la actualidad?

e) ¿Qué competencias/habilidades consideras útiles para gestionar con éxito el emprendimiento?

f) ¿En qué nivel educativo se deben adquirir?

g) En el caso en que varíe ¿En qué nivel educativo se están impartiendo en la actualidad?

h) ¿Qué ayudas económicas existen para la creación de empresas?

i) ¿Qué organismos oficiales asesoran en la creación de empresas? ¿Existe coordinación entre estos ¿Qué organismos oficiales asesoran en la creación de empresas? ¿Existe coordinación entre estos
organismos?

¿Qué formación incorporarias en el sistema educativo (ESO, FP y BACH) para fomentar el emprendimiento y en qué nivel formativo?

k) ¿Qué utilidad tienen las Redes de Emprendimiento?

5. Conclusiones 


\section{Notas}

1 El texto que se presenta se vincula al Proyecto de Investigación “De los tiempos educativos a los tiempos sociales: la construcción cotidiana de la condición juvenil en una sociedad de redes. Problemáticas específicas y alternativas pedagógicosociales" (proyecto coordinado EDU2012-39080-C07-00) y al subproyecto "De los tiempos educativos a los tiempos sociales: El impacto de la educación en la red de emprendimiento de los jóvenes. Competencias e innovaciones curriculares" (EDU2012-39080-C07-06), cofinanciado en el marco del Plan Nacional I+D+i con cargo a una ayuda del Ministerio de Economía y Competitividad, y por el Fondo Europeo de Desarrollo Regional (FEDER, 2007-2013).

\section{CÓMO CITAR ESTE ARTÍCULO / HOW TO CITE THE ARTICLE}

Luis Rico, M.l., Palmero Cámara, C. \& Escolar Llamazares, M.C. (2015). Impacto de la educación en el emprendimiento. Making-of y análisis de tres grupos de discusión. Pedagogía Social. Revista Interuniversitaria, 25, 221-250. DOI:10.7179/PSRI_2015.25.10

Fecha de recepción del artículo / received date: 23.VI.2014

Fecha de revisión del artículo: / reviewed date: 23.VI.2014

Fecha de aceptación final / accepted date: 11.XI.2014

\section{DIRECCIÓN DE LOS AUTORES/ AUTHORS' ADDRESS}

Carmen Palmero Cámara. M. Isabel Luis Rico, María del Camino Escolar Llamazares. Facultad de Humanidades y Educación. Universidad de Burgos. Dirección de correo/e-mail: : cpalmero@ubu.es, miluis@ubu.es, cescolar@ubu.es

\section{PERFIL ACADÉMICO / ACADEMIC PROFILE}

M. Isabel Luis Rico Doctora en Ciencias de la Educación. Premio Extraordinario de Doctorado. Licenciada en Pedagogía y Especialista Universitario en Servicios Sociales. Profesora Ayudante Doctor del Área de Teoría e Historia de la Educación en la Universidad de Burgos. Acreditada para Contratado Doctor. Profesora de Master en la Universidad de Deusto. Miembro de los grupos y redes de investigación internacional Formadesa, Ociogune y Resortes. Dirige diferentes trabajos fin de grado, tesis doctoral y mantiene una línea de investigación sobre grupos desfavorecidos y vulnerables con proyectos de investigación competitivos financiados por el Plan Nacional de I+D+l y la Consejería de Educación de la Junta de Castilla y León. Autora de monografías y artículos en revistas científicas nacionales e internacionales. Colabora en tareas de gestión y docencia de los Programa de Formación Universitaria de Personas Mayores en la Universidad de Burgos.

Carmen Palmero Cámara. Doctora en Filosofía y Ciencias de la Educación. Premio Extraordinario de Doctorado. Licenciada en Pedagogía y en Psicología. Profesora Titular de Universidad del Área de Teoría e Historia de la Educación en la Universidad de Burgos. Acreditada para Catedrática de Universidad. Profesora contratada en las Universidades de Magallanes (Chile) y Cristóbal Colón (México). Participa en acciones bilaterales de la AECl. Miembro de los grupos y redes de investigación internacional Formadesa, G-21-Asociación Europea por la Innovación, Ociogune y Resortes. Ha dirigido diferentes tesis doctorales y mantiene una línea de investigación sobre grupos desfavorecidos y vulnerables con proyectos de investigación competitivos financiados por el Plan Nacional de I+D+I y la Consejería de Educación de la Junta de Castilla y León. Autora de monografías y artículos en revistas científicas nacionales e internacionales. Evaluadora de la Agencia Catalana de Calidad Universitaria. 
Es Directora de los Programas de Formación Universitaria de Personas Mayores en la Universidad de Burgos y Secretaria de la Asociación Estatal de Programas Universitarios para Mayores.

María del Camino Escolar Llamazares. Doctora en Psicología por la Universidad de Salamanca, Master en Terapia de Conducta y Profesora Ayudante Doctor del Área de Personalidad, Evaluación y Tratamiento Psicológico de la Universidad de Burgos. Acreditada como Profesor Contratado Doctor. Ha colaborado como terapeuta e investigadora en la Unidad de Atención Psicológica de la Universidad de Salamanca y ha trabajado como Orientadora en la Unidad de Empleo de la Universidad de Burgos. Dirige diferentes trabajos fin de grado, tesis doctoral y sus investigaciones principales se centran en los problemas de ansiedad ante los exámenes universitarios, ansiedad ante la búsqueda de empleo y ante el emprendimiento. Además, colabora como investigadora en proyectos de investigación competitivos financiados por el Plan Nacional de I+D+l. Autora de monografías y artículos en revistas científicas nacionales e internacionales. Ocupa el cargo de Delegada del Rector para el Plan de Acción tutorial, Orientación y Mentoría de la Universidad de Burgos. 